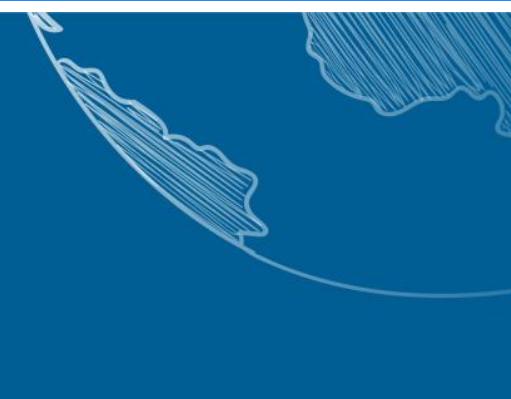

\title{
APROXIMAÇÕES TEÓRICO-CONCEITUAIS ACERCA DOS DIREITOS HUMANOS
}

\author{
THEORETICAL-CONCEPTUAL APPROACHES ON HUMAN RIGHTS
}

\author{
APROXIMACIONES TEORICO-CONCEITUALES DE LOS \\ DERECHOS HUMANOS
}

\author{
José Rodrigo Barth Adams ${ }^{1}$ Mariana Pfeifer ${ }^{2}$ Elison Antonio Paim ${ }^{3}$
}

\begin{abstract}
RESUMO
O presente artigo apresenta um debate histórico acerca dos Direitos Humanos desde suas primeiras expressões apontadas enquanto dever e seus vínculos ao ideal liberal, até sua vinculação ao quadro dos diretos civis, políticos e sociais no marco da constituição da cidadania no século XX. Aponta-se seu marco com a Declaração Universal dos Diretos Humanos de 1948, e indica os Direitos Humanos como campo de disputas e composto por uma dimensão contraditória. É problematizada a necessidade de um Estado democrático para a proteção e materialização dos Direitos Humanos, cujo debate é atravessado pelo campo de disputas travadas no âmbito da sociedade civil. Realiza-se uma análise das expressões da democracia e de regimes ditatoriais na América Latina do século XX e a introdução das medidas de cunho neoliberal, evidenciando seus rebatimentos para os Direitos Humanos do ponto de vista da sua necessária vinculação ao enfrentamento e a superação das desigualdades sociais.
\end{abstract}

PALAVRAS-CHAVE: Direitos Humanos, Estado e Democracia.

\section{ABSTRACT}

This article presents a historical debate about Human Rights from its first expressions as a duty and its links to the liberal ideal, until its connection with the civil, political and social framework within the framework of the constitution of citizenship in the 20th century. Its landmark is marked by the Universal Declaration of Human Rights of 1948, and it indicates Human Rights as a field of disputes and is composed of a contradictory dimension. The need for a democratic State for the protection and

\footnotetext{
${ }^{1}$ Graduado em Ciências Sociais (2008), mestre (2010) e doutor (2019) em Educação, todos pela Universidade Federal de Santa Catarina (UFSC). Professor de sociologia do Instituto Federal de Santa Catarina (IFSC), com atuação no ensino médio integrado no Campus Itajaí. Email: joserodrigoadams@yahoo.com.com

${ }^{2}$ Graduada (2003) e Mestre (2006) em Serviço Social pela Universidade Federal de Santa Catarina (UFSC). Doutora (2013) em Educação pela Universidade Federal do Paraná (UFPR). Professora adjunta do Departamento de Serviço Social da UFSC, com atuação no curso de Graduação e no Programa de Pós-Graduação em Serviço Social (PPGSS). Atualmente é tutora do Programa de Educação Tutorial em Serviço Social (PET-SSO) da UFSC e membro do Grupo de Estudos e Pesquisas em Serviço Social (GEPSS). Email: marianapfeifer@ gmail.com

${ }^{3}$ Graduado em História (1986) pela Universidade Federal de Santa Maria (UFSM). Mestre em História (1996) pela Pontifícia Universidade Católica de São Paulo (PUC-SP) e doutor (2005) em Educação pela Universidade Estadual de Campinas (UNICAMP). Professor adjunto da Universidade Federal de Santa Catarina (UFSC) no Departamento de Metodologia de Ensino (MEN). Professor Permanente do Programa de Pós-Graduação em Educação (PPGE). Líder do Grupo de Pesquisas Patrimônio, Memória e Educação (PAMEDUC-UFSC), vice-líder do Grupo de Pesquisas Rastros (USF), membro do Grupo de Pesquisas Kairós (Unicamp). Email: elison0406@gmail.com
}

\begin{tabular}{l|l|r} 
Recebido em: 25/03/2019 & Aceito em: 30/04/2019 & Pg. 50 - 73
\end{tabular}




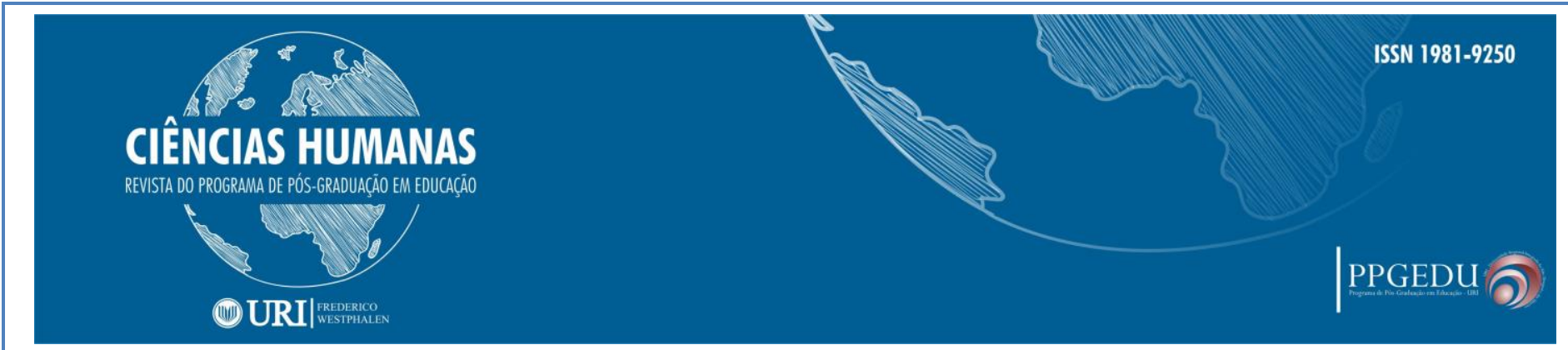

materialization of Human Rights is debated, whose debate is crossed by the field of disputes within civil society. An analysis of the expressions of democracy and dictatorial regimes in Latin America of the twentieth century and the introduction of neoliberal measures are presented, evidencing their refutations for Human Rights from the point of view of their necessary link to the confrontation and the overcoming of inequalities social rights.

KEYWORDS: Human Rights, State and Democracy.

\section{RESUMEN}

El presente artículo presenta un debate histórico sobre los Derechos Humanos desde sus primeras expresiones apuntadas en cuanto deber y sus vínculos al ideal liberal, hasta su vinculación al cuadro de los derechos civiles, políticos y sociales en el marco de la constitución de la ciudadanía en el siglo XX. Se apunta su marco con la Declaración Universal de los Derechos Humanos de 1948, e indica los Derechos Humanos como campo de disputas y compuesto por una dimensión contradictoria. Es problematizada la necesidad de un Estado democrático para la protección y materialización de los Derechos Humanos, cuyo debate es atravesado por el campo de disputas trabadas en el ámbito de la sociedad civil. Se realiza un análisis de las expresiones de la democracia y de regímenes dictatoriales en América Latina del siglo XX y la introducción de las medidas de cuño neoliberal, evidenciando sus rebajas hacia los Derechos Humanos desde el punto de vista de su necesaria vinculación al enfrentamiento y la superación de las desigualdades social.

PALABRAS CLAVE: Derechos Humanos, Estado y Democracia.

\section{POR QUE FALAR EM DIREITOS HUMANOS?}

A Declaração Universal dos Direitos Humanos (Declaração Universal) proclamada pela Assembleia Geral das Nações Unidas em Paris, em 10 de dezembro de 1948, completou 70 anos agora em 2018. Seu surgimento se deu no contexto póssegunda grande guerra que, envolvendo diversos países, de 1939 a 1945, foi um dos conflitos bélicos mais letais na história recente, cenário da utilização de armas nucleares nas cidades de Hiroshima e Nagasaki e genocídios como o holocausto na Alemanha, por exemplo, e resultou na morte de mais de 50 milhões de pessoas, destruição de cidades e poluição do meio ambiente. Diante de tal barbárie, a Declaração Universal foi elaborada indicando para a humanidade outro caminho, fundamentado no respeito à dignidade humana e proteção universal de direitos, sendo até hoje um documento marco para os Direitos Humanos em todo o mundo.

Nestes 70 anos de história, a Declaração Universal "colocou o ser humano no centro do direito internacional" (POOLE, 2007, p. 97). A partir de seus princípios e diretrizes, os países signatários, muitas instituições, corporações e empresas comprometeram-se a respeitar os direitos fundamentais colocados no documento, tais como: "todo ser humano tem direito à vida, à liberdade e à segurança pessoal", "a escravidão e o tráfico de escravos serão proibidos em todas as suas formas"; "ninguém será submetido à tortura, nem a tratamento ou castigo cruel, desumano ou degradante"

\begin{tabular}{l|l|l} 
Recebido em: 25/03/2019 & Aceito em: 30/04/2019 & Pg. 50 - 73
\end{tabular}




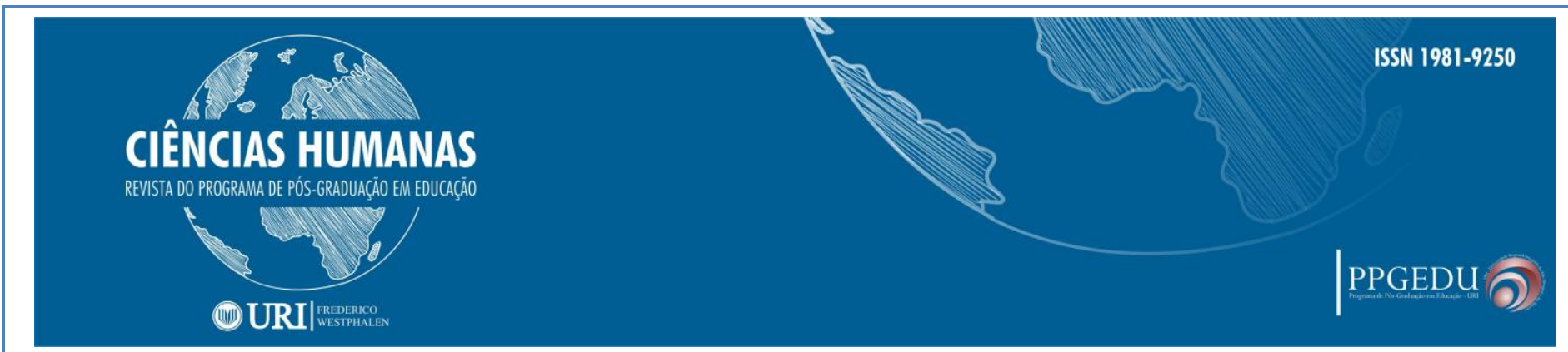

(ONU, 2016a). Acordos, pactos, documentos, leis, políticas e projetos vêm sendo desenvolvidos em todo o globo, assim como se constituiu um movimento mundial em torno de organizações e movimentos sociais para a defesa e a promoção dos Direitos Humanos.

Não obstante os avanços do ponto de vista político-jurídico e organizativo, o mundo ainda vem sendo palco cotidiano de violações dos Direitos Humanos. Uma das questões mais emblemáticas do cenário recente é o problema global dos refugiados onde, segundo Informe 2017/2018 sobre o estado os Direitos Humanos no mundo da Anistia Internacional ${ }^{4}$, mais de 21 milhões de pessoas se obrigaram a fugir de suas cidades e países em busca de proteção diante das situações de conflitos armados, opressões, privações e pobreza extrema (ANISTIA INTERNACIONAL, 2018). Na Somália são mais de um milhão de pessoas deslocadas. Os conflitos na Síria já resultam em mais de 5 milhões de refugiados. Na América, a situação dos refugiados também é alarmante, "segundo o ACNUR, a agência de refugiados da ONU, mais de 57 mil pessoas de Honduras, Guatemala e El Salvador buscaram asilo em outros países" (ANISTIA INTERNACIONAL, 2018, p.31).

$\mathrm{O}$ continente africano tem sido palco de inúmeras violências praticadas pelo Estado Islâmico, como bombardeios no Egito, atentados suicidas, cativeiro e escravização de mulheres e crianças. Jornalistas e defensores de direitos humanos são reprimidos por governos com controle de manifestações na internet. Conflitos armados, cercos ilegais, centenas de execuções, repressão legal aos direitos das pessoas lésbicas, gays, bissexuais, travestis, transexuais ou transgêneros (LGBTs), demolição de propriedades dos palestinos, bloqueio à circulação de pessoas e de bens em Gaza, cortes de energia em Israel, escassez de água na Tunísia, conflitos e crise humanitária no Iêmen com destruição de sistemas de água, educação e saúde (ANISTIA INTERNACIONAL, 2018).

No continente Americano a situação de violações também são cotidianas. A América Latina e o Caribe são palco das maiores taxas de violência contra as mulheres. Extermínio, criminalização e tomada de terras de povos indígenas e camponeses agricultores na Argentina, Brasil, Bolívia, Canadá, Chile, Colômbia, Equador, Honduras, Nicarágua e Peru. Epidemia de cólera no Haiti. Mais de 34 mil pessoas no México desapareceram, foram levadas a força, torturadas, executadas e vítimas de maus-tratos pelas forças de segurança. Abuso da violência no controle da fronteira EUA-México. Revogação de leis de proteção e crescimento da privação de direitos em diversos países. No Brasil, há uma grande onda de homicídios ilegais em várias cidades, superlotação e condições subumanas nos presídios. Os defensores de Direitos Humanos

\footnotetext{
${ }^{4}$ A Anistia Internacional é um movimento global que realiza ações e campanhas para que os Direitos Humanos internacionalmente reconhecidos sejam respeitados e protegidos. Está presente em mais de 150 países.

\begin{tabular}{l|l|l}
\hline Rev. Ciências Humanas & Frederico Westphalen, RS & Jan./abr. 2019 \\
\hline
\end{tabular}

\begin{tabular}{l|l|l} 
Recebido em: 25/03/2019 & Aceito em: 30/04/2019 & Pg. 50 - 73
\end{tabular}
}




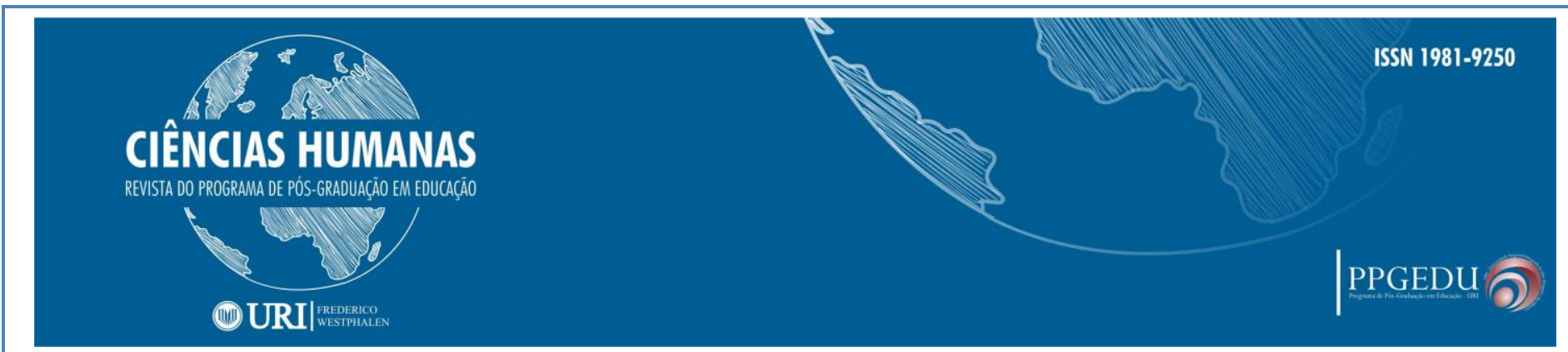

têm sido alvo de ameaças, ataques e assassinatos, especialmente em áreas rurais, entre tantas outras manifestações (ANISTIA INTERNACIONAL, 2018).

Diante destes desafios colocados pela conjuntura atual e da gravidade das situações de violências à dignidade humana, a problemática dos Direitos Humanos torna-se importante para a sociedade contemporânea, tanto em nível local quanto em nível regional e mundial, individual e/ou coletivamente. E, considerando que os Direitos Humanos são contraditória e cotidianamente afirmados e ampliados, por um lado, e negados e violados, por outro, a questão precisa ser enfrentada teórica, politica e efetivamente.

Neste sentido, o presente artigo busca apresentar elementos históricos e conceituais acerca dos Direitos Humanos, evidenciando aspectos que reverberam na construção e/ou desconstrução destes direitos. Importa desnudar os contextos e projetos societários mais amplos que acabam por fortalecer ou enfraquecer a efetivação plena dos Direitos Humanos. A discussão histórico-crítica e sociológica aqui apresentada insere o debate dos Direitos Humanos no contexto da cidadania, da democracia e do papel do Estado. Considera-se que os Direitos Humanos mobilizam uma série de atores em diferentes lugares e espaços, por isso reitera-se a importância da sociedade civil e da vinculação aos interesses das classes subalternizadas para um possível potencial emancipatório e democrático dos Direitos Humanos. Tais aspectos são relevantes, pois podem engendrar criticidade a análise e a defesa dos Direitos Humanos em diferentes áreas na contemporaneidade, que tem potencial para contribuir na construção de outro paradigma civilizatório, alicerçado na efetivação plena da dignidade humana, mediante a garantia de direitos a todos os seres humanos.

\section{OS DIREITOS HUMANOS NO CURSO DA HISTÓRIA}

Os Direitos Humanos são produtos do desenvolvimento histórico, fruto de lutas sociais e políticas travadas por diversos atores em diferentes momentos da história. Ainda na antiguidade, é possível encontrar expressões de direitos como o Código de Hamurabi, conjunto de leis escritas mais antigas da Mesopotâmia, de cerca de 1700 a.C., que indicaram deveres relativos ao trabalho, família, propriedade e a escravidão no contexto da época. No debate acerca da história dos Direitos Humanos, dentre as "escolas" que influenciaram significativamente a concepção atual dos "Direitos do Homem”, pode-se destacar a tradição grega e a tradição judaico-cristã que, segundo Poole (2007, p.16), são exemplos significativos de defesa ao ser humano. Fundada em Chipre, por Zenão de Cítio (335-263 a.C), a escola estoica grega pregava a existência de uma lei natural segundo a qual os seres humanos tinham em comum uma centelha de divindade, sendo que a terra e o cosmos faziam parte de um sistema indissolúvel, propugnando, deste modo, a crença de direitos universais para todos. A tradição

\begin{tabular}{l|l|l}
\hline Rev. Ciências Humanas & Frederico Westphalen, RS & Jan./abr. 2019
\end{tabular}

\begin{tabular}{l|l|l} 
Recebido em: 25/03/2019 & Aceito em: 30/04/2019 & Pg. 50 - 73
\end{tabular}




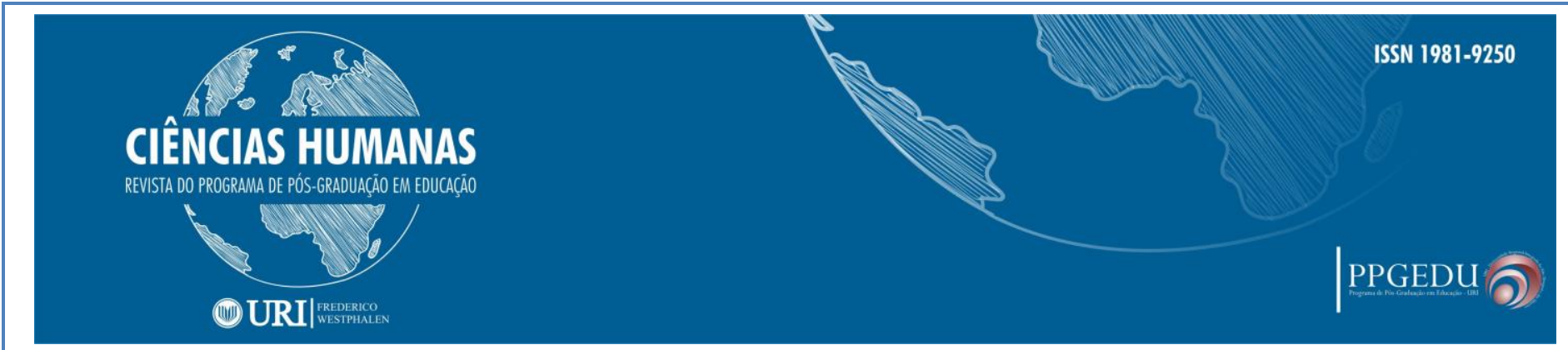

judaico-cristã, por seu turno, também contribuiu grandemente para a concepção moderna dos Direitos Humanos ao defender os marginalizados, excluídos, pobres e enfermos (POOLE, 2007, p.16).

Outhwaite e Bottomore (1996) lembram que as ideias de direitos e cidadania aparecem em vários momentos da história, como na Grécia e Roma antigas. $O$ "cidadão" grego tinha condições de manifestar sua opinião sobre os rumos sociais a serem tomados, contudo, somente homens "livres" eram considerados cidadãos e gozavam deste status. Mulheres e estrangeiros não eram considerados cidadãos. A cidadania estava vinculada a direitos políticos que diziam respeito a esta coletividade seleta. Tinha-se, portanto, uma cidadania um tanto quanto restrita. Porém, as experiências históricas até então desenvolvidas, enfatizavam sobremaneira a noção de dever em detrimento da noção de direitos, que somente emerge a partir da modernidade. A concepção moderna de cidadania "possui um caráter próprio", pois diz respeito à relação entre "direitos e deveres dos cidadãos". Nessa direção, Pinsky (2003) argumenta que as declarações que envolvem os Direitos Humanos na França e nos Estados Unidos, do terço final do século XVIII, inverteram o princípio dos “deveres dos súditos" vigente até então, instaurando a lógica moderna dos "direitos dos cidadãos", esta que culminou com o conjunto de lutas travadas em torno da ampliação do conceito e das políticas voltadas a cidadania, especialmente no século XX.

A Declaração da Independência dos Estados Unidos, de 1776, afirma que "que todos os homens são criados iguais, que são dotados pelo Criador de certos direitos inalienáveis, que entre estes estão a vida, a liberdade e a procura da felicidade" ${ }^{\text {. }} \mathrm{Na}$ Declaração de Virgínia, do mesmo ano, são proclamados os direitos à vida, à propriedade, à liberdade de imprensa e à liberdade religiosa. Já a Declaração do Homem e do Cidadão Francesa, de 1789, culminante da Revolução Francesa, influenciada pela doutrina dos direitos naturais, coloca em seus dezessete artigos um conjunto de garantias e liberdades individuais e coletivas universais dos homens, tais como a garantia de propriedade e de igualdade perante a lei, que permanecem nas declarações mais recentes.

Tal arcabouço do final do século XVIII coloca os indivíduos no centro, reconhecidos na letra da lei como sujeitos de direitos e, do ponto de vista jurídicopolítico, "iguais" entre si. Cabe ressaltar que estes direitos estão vinculados à noção de liberdade individual em detrimento da noção de direitos coletivos, que é um dos elementos da concepção dos Direitos Humanos na contemporaneidade. A acepção de liberdade não se coloca mais restrita ao poder dos nobres ou do clero, como na Idade Média, mas a noção de que todos os indivíduos nascem livres e iguais perante a lei.

É preciso lembrar que a versão moderna dos Direitos Humanos nasce no contexto

${ }_{5}^{5}$ Disponível em http://www.uel.br/pessoal/jneto/gradua/historia/recdida/declaraindepeEUAHISJNeto.pdf

\begin{tabular}{l|l|l}
\hline Rev. Ciências Humanas & Frederico Westphalen, RS & Jan./abr. 2019
\end{tabular}

\begin{tabular}{l|l|l} 
Recebido em: 25/03/2019 & Aceito em: 30/04/2019 & Pg. 50 - 73
\end{tabular}




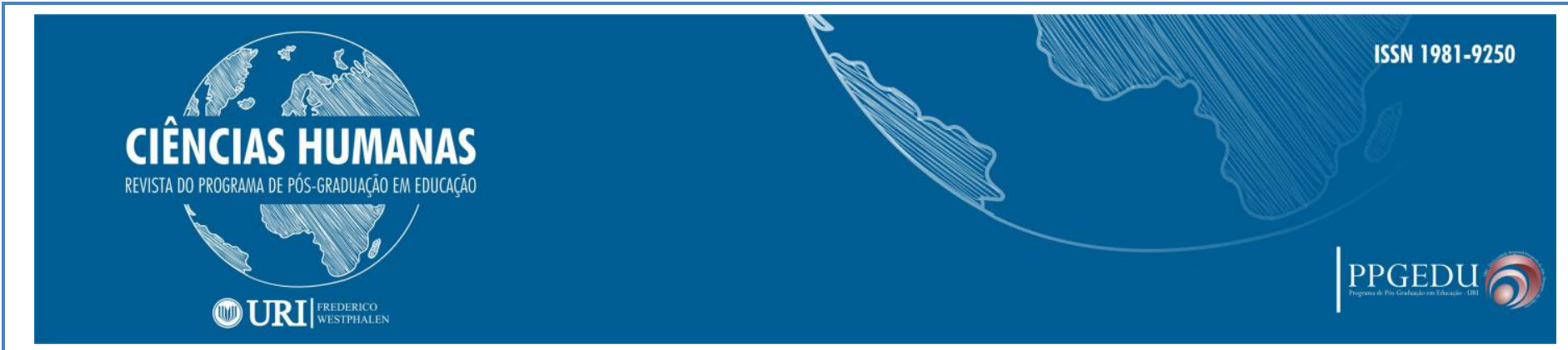

histórico de surgimento da sociedade capitalista, desencadeada com a decadência do Estado absolutista, no contexto de busca por liberdades frente ao poder absoluto do Estado e na ascensão da burguesia como classe revolucionária. É, portanto, na atmosfera capitalista que se constitui o arcabouço jurídico-político dos Direitos Humanos, o que significa, sob a égide do capital, uma limitação do ponto de vista de sua democratização, pois esta sociedade se assenta nos interesses de uma classe em particular, o que, entre outros fatores, faz encontrar obstáculos a plena efetivação dos Direitos Humanos. Outra importante objeção que se fez aos Direitos Humanos diz respeito ao seu excesso de abstração, pois não seriam expressão de um conjunto mais amplo de culturas existentes no mundo, sendo hegemonicamente ocidental. Sua pretensa universalidade seria, portanto, uma abstração.

Um elemento histórico-político a ser considerado na análise do desenvolvimento dos Direitos Humanos, diz respeito ao Estado. Costa (2006, p. 02) ajuda-nos a compreender que o advento do Estado Moderno está ancorado em uma concepção que o coloca como protetor da coletividade, ou seja, "como instância capaz de proteger os seus integrantes". Com as devidas diferenças, os chamados "jusnaturalistas", dentre eles Locke, Hobbes e Rousseau, buscaram explicar racionalmente a gênese do Estado argumentando que o "homem possui direitos naturais e que é o consentimento expresso no pacto feito entre os indivíduos que dá origem a sociedade política" (COSTA, 2006, p.2), ou seja, ao Estado. Nessa perspectiva, os indivíduos abririam mão de sua liberdade "natural", deixando a cargo do Estado sua proteção. O Estado moderno aparece como um poder soberano e se caracteriza "pela ideia de soberania do poder e autonomia baseada no uso da razão" (COSTA, 2006, p.4). O Estado capitalista, por seu turno, "se legitima para assegurar o direito à propriedade privada, à liberdade econômica, segurança pessoal e liberdade do cidadão" (COSTA, 2006, p.4).

Os Direitos Humanos foram se metamorfoseando e incorporando outros direitos nos diferentes contextos históricos que se desenrolaram até os dias atuais. $\mathrm{Na}$ bibliografia relacionada aos Direitos Humanos, alguns intelectuais classificam esses direitos em diferentes gerações. Esta interpretação tem estreita relação com a discussão sobre cidadania feita por Marshall (1967), que um dos pioneiros na explicação dos Direitos Humanos entendendo-os a partir de suas diferentes gerações. Para Marshall, a conquista sócio-histórica dos direitos está diretamente relacionada à conquista da cidadania, sendo a geração dos direitos civis do século XVIII, os direitos políticos do século XIX e os direitos sociais do século XX.

$\mathrm{O}$ conjunto de direitos civis corresponde aqueles que se desenrolaram nas declarações da França e dos Estados Unidos, já citadas, direitos necessários à liberdade individual no contexto da sociedade capitalista, como a "liberdade de ir e vir, liberdade de imprensa, pensamento de fé, direito à propriedade e de concluir contratos válidos e o direito à justiça" (TONET, 2004, p.149). Especialmente no que ser refere ao direito à

\begin{tabular}{l|l|l} 
Recebido em: 25/03/2019 & Aceito em: 30/04/2019 & Pg. 50 - 73
\end{tabular}




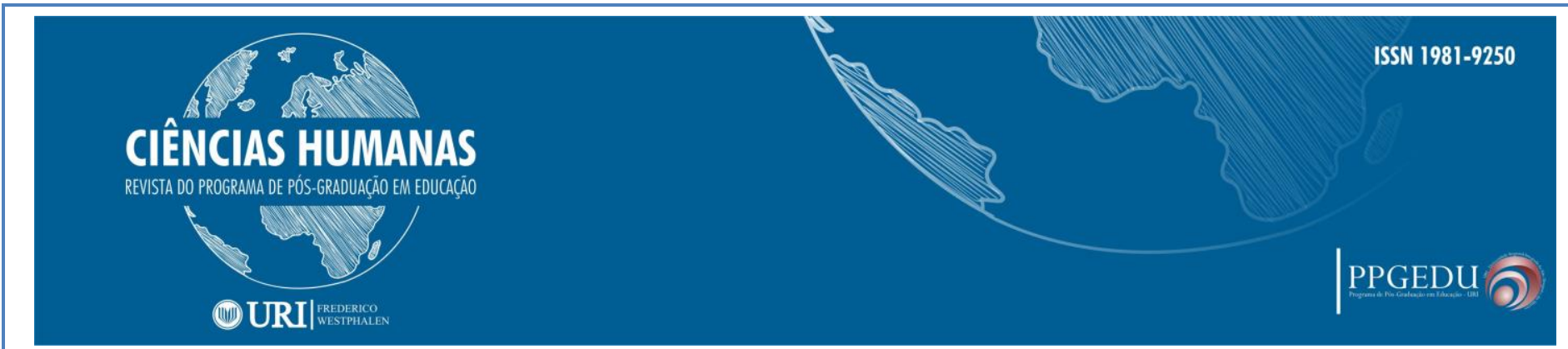

liberdade, é relevante destacar que na primeira metade do século XIX, ocorreram abolições de escravatura no continente americano, colocando os negros escravizados em condição de liberdade. No Brasil, a abolição só ocorreu em 1888, com a Lei Áurea.

Os direitos civis foram necessários para contestar regimes de governos autoritários que cerceavam as liberdades individuais, tais como os regimes absolutistas europeus anteriores a constituição dos Estados modernos e os regimes totalitários que se materializaram ao longo do século XX, como o fascismo e o nazismo. No Brasil, foram exigidos pelos grupos populares mais incisivamente no contexto da ditadura militar (1964-1985) que buscou limitar as liberdades por meio de práticas como a censura. Atualmente, estes direitos estão expressos na Constituição brasileira de 1988, cujo artigo $5^{\circ}$ afirma que "todos são iguais perante a lei, sem distinção de qualquer natureza" e garante uma série de liberdades, tais como "a livre manifestação de pensamento" e "livre a expressão da atividade intelectual, artística, científica e de comunicação, independentemente de censura ou licença” (BRASIL, 2016a).

Os direitos políticos referem-se ao direito de participação no exercício do poder político, como direito ao voto e de exercer cargos públicos. O voto das mulheres, por exemplo, foi uma luta histórica que culminou na obtenção do direito a votar em vários países no século XIX e XX. O sufrágio universal foi conquistado na Bélgica em 1893 e na Austrália em 1902. No Brasil, somente na década de 1930 é que as mulheres tiveram este direito assegurado. Atualmente, todos os cidadãos entre 18 e 70 anos são obrigados a votar no Brasil, sendo facultativo a jovens entre 16 e 17 anos. O direito ao voto foi um passo importante no processo de lutas pela efetivação dos direitos políticos, todavia, estes direitos também sinalizam para a participação plena nas decisões políticas. Nessa direção, percebe-se que só nas ultimas décadas é que as mulheres começaram a exercer cargos públicos de relevância política e a participar mais diretamente no parlamento. Por mais que tenha ocorrido uma ampliação da participação feminina em várias esferas sociais, ainda é preciso avançar neste quesito em âmbito nacional, “o Brasil está na lanterna ( $161^{\mathrm{a}}$ posição) de um ranking de 186 países sobre a representatividade feminina no poder executivo, atrás de todos os outros países do continente americano" (ROSSI, 2019, p.1).

Diferentemente de Marshall (1967), cabe ressaltar que Santos (2002, p. 27) classifica "os direitos civis e políticos" conjuntamente como direitos de primeira geração, vinculados ao panorama do século XVIII e XIX. Santos (2002, p. 31) indica como segunda geração o que ele chama de "direitos de igualdade", que se efetivam com o advento do Estado de Bem Estar Social, isto é, "são os direitos sociais, econômicos e culturais. Destacam-se as reivindicações em torno do direito ao trabalho; à organização sindical; à seguridade social; à justa remuneração, dentre muitos outros" (SANTOS, 2002, p. 31). Os “direitos dos povos" são considerados por Santos (2002, p. 31) como os de terceira geração e dizem respeito ao "direito à existência; preservação de sua

\begin{tabular}{l|l|l} 
Recebido em: 25/03/2019 & Aceito em: 30/04/2019 & Pg. 50 - 73
\end{tabular}




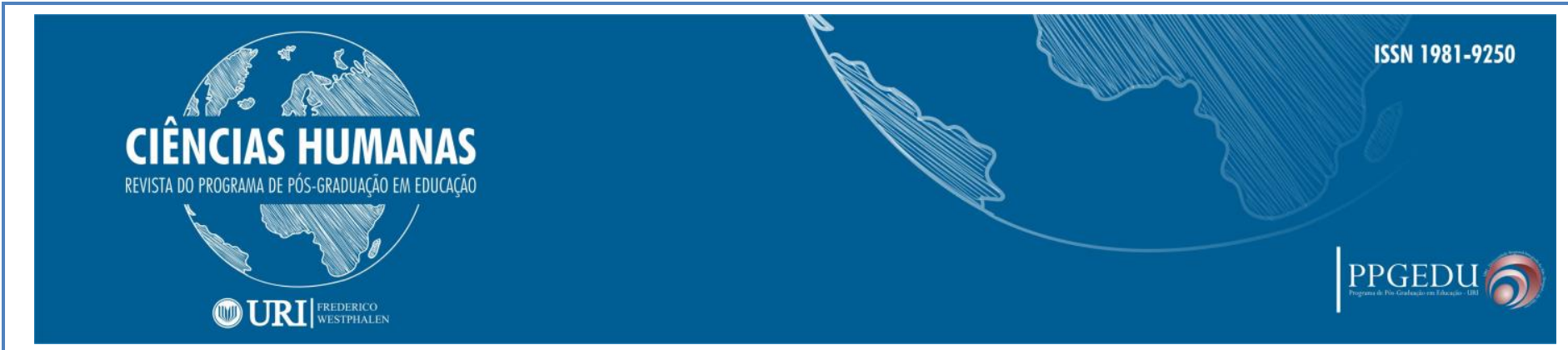

cultura; direito à paz e ao pleno desenvolvimento". O autor ainda indica uma quarta geração que se referem, entre outras coisas, à democracia, à informação e ao pluralismo. Marshall (1967), por sua vez, vai colocar que os direitos sociais são a terceira geração dos direitos. Fruto dos processos históricos do século XX, referem-se "a tudo que vai desde o direito de participar, por completo, da herança social e levar uma vida de um ser civilizado de acordo com os padrões que prevalecem na sociedade" (MARSHALL, 1967, p.63-64).

$\mathrm{O}$ século $\mathrm{XX}$ foi palco de intensas lutas sociais em torno de direitos que se materializam em documentos importantes, como a Declaração dos Direitos do Povo Trabalhador e Explorado da antiga União Soviética (Constituição Soviética - Revolução Bolchevique $)^{6}$, de 1918, que visava "suprimir toda exploração do homem pelo homem" e "abolir completamente a divisão da sociedade em classes". O Pacto da Liga das Nações, aprovado na Conferência de Versalhes ${ }^{7}$, em 1920, também é outro documento importante que buscava "garantir a paz e a segurança" das nações depois do mundo ser dilacerado pela primeira grande guerra, que perdurou de 1914 até 1918. Após outras importantes conquistas deste período, como a Abolição da Pena de Morte na Espanha, de 1932, e a Convenção Internacional relativa à repressão do tráfico de mulheres, de 1933, o mundo novamente viu explodir outro conflito mundial no ano de 1939. A segunda guerra mundial se estendeu até o ano de 1945, deixando um saldo de milhões de pessoas mortas. Ao final deste conflito bélico, foi criada a Organização das Nações Unidas (ONU), órgão que construiu a Declaração Universal dos Direitos Humanos (Declaração Universal).

No Brasil, a construção dos direitos sociais e trabalhistas teve um longo caminho. Desde o início do século XX, muitas lutas foram travadas pelas classes populares, especialmente encabeçadas pelo movimento operário, tais como as paralizações de setores metalúrgico, construção civil e alimentício ocorridos em São Paulo, no ano de 1907. Sob influência do movimento operário em nível mundial, os trabalhadores reivindicavam direito a férias, a assistência médica, jornada de trabalho de oito horas e o fim do trabalho de crianças. Em 1917, também ocorreu uma greve geral desencadeada após a morte de um jovem trabalhador pela polícia. Na pauta também estavam a reivindicação de direitos trabalhistas e sociais que só viriam nas próximas décadas. Ponderando sobre os direitos conquistados na Era Vargas, que foi de 1930 a 1945, Antunes (2006, p. 86) coloca que os trabalhadores "lutavam há anos por férias, redução da jornada de trabalho, descanso semanal remunerado etc. Vargas, ao atender estas reivindicações, o fez como se fosse um dádiva aos trabalhadores, como se a legislação trabalhista fosse um presente para os trabalhadores". Contudo, não é possível

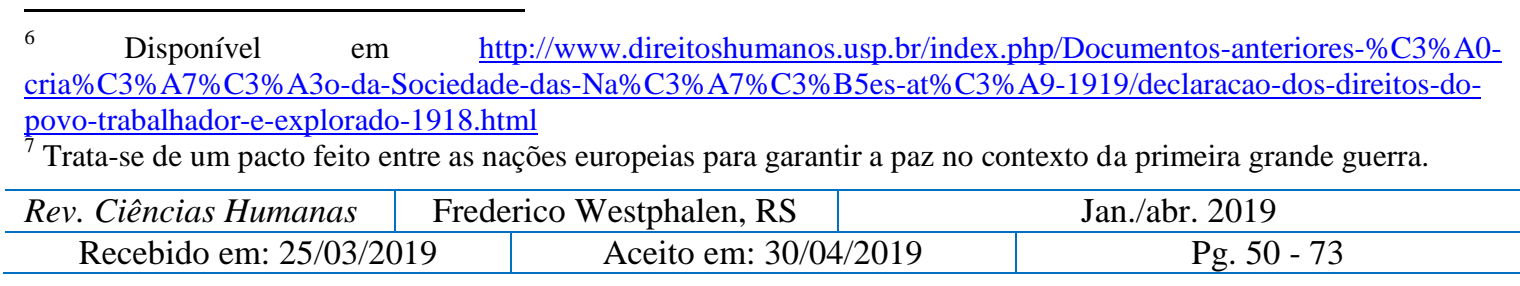




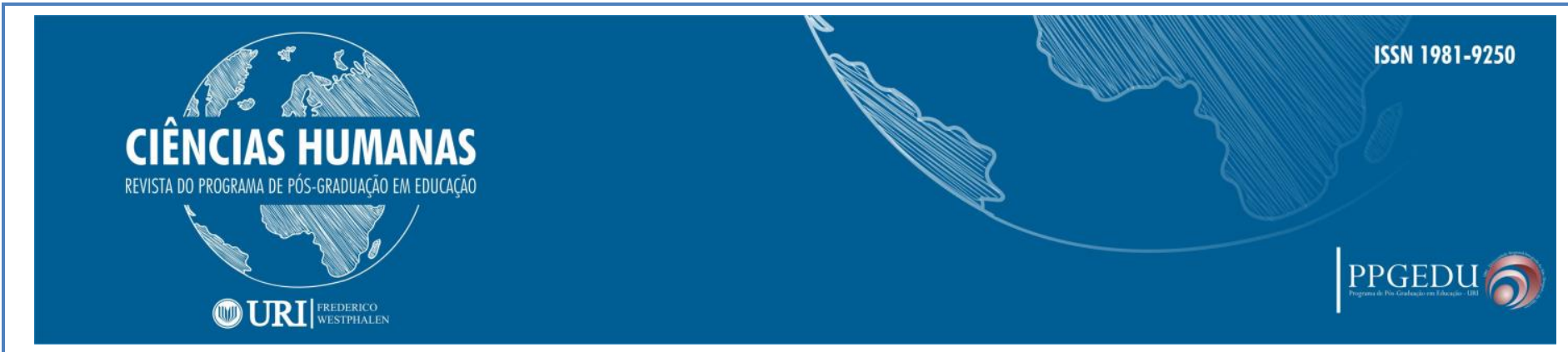

desconsiderar o importante papel desempenhado pelas classes populares, por meio de um processo de intensas lutas, tencionando a correlação de forças e disputando o fundo público. Portanto, pode-se afirmar que se desenvolveu um processo dialético e contraditório de conquista e de concessão de direitos. A Consolidação das Leis Trabalhistas (CLT) ocorreu no ano de 1943, dois anos antes do término da segunda guerra mundial. Após a saída de Vargas em 1945, o Brasil passou por um período democrático que se estendeu até 1964, quando, novamente, foi instituída uma ditadura que obstaculizou o uso fruto de direitos civis e políticos.

No desenrolar do século XX, a sucessiva incorporação de direitos civis, políticos, sociais e trabalhistas no arcabouço jurídico-político dos países, consubstanciou um processo de construção da cidadania, fundamental para a efetivação dos Direitos Humanos. Considera-se que o Estado e a democracia tem papel determinante neste processo, debate que será realizado na sessão sequente. Cabe aqui problematizar acerca da relação entre cidadania e Direitos Humanos. Para Coutinho (2000, p. 50),

cidadania é a capacidade conquistada por alguns indivíduos, ou (no caso de uma democracia efetiva) por todos os indivíduos, de se apropriarem dos bens socialmente criados, de atualizarem todas as potencialidades de realização humana abertas pela vida social em cada contexto historicamente determinado.

Para Coutinho, a cidadania não é "dada uma vez para sempre", pois precisa ser constantemente buscada por meio das lutas. Também pode ser construída "de-cimapara-baixo", pois depende das lutas travadas pelas classes subalternas para se efetivar, na qual a luta por Direitos Humanos e pela cidadania se entrelaçam e constituem duas frentes importantes no processo de constituição das sociedades modernas. Para Benevides (2017, p. 04), contudo, a ideia de cidadania diz

respeito a uma determinada ordem jurídico-política de um país, de um Estado, no qual uma Constituição define e garante quem é cidadão, que direitos e deveres ele terá em função de uma série de variáveis tais como a idade, o estado civil, a condição de sanidade física e mental, o fato de estar ou não em dívida com a justiça penal etc. Os direitos do cidadão e a própria ideia de cidadania não são universais no sentido de que eles estão fixos a uma específica e determinada ordem jurídico-política. Daí, identificamos cidadãos brasileiros, cidadãos norte-americanos e cidadãos argentinos, e sabemos que variam os direitos e deveres dos cidadãos de um país para outro.

Pode-se afirmar que a expressão máxima do processo de construção dos Direitos Humanos em nível mundial, tanto por seu conteúdo quanto por seu valor simbólico, é a Declaração Universal dos Direitos Humanos (Declaração Universal). A Organização das Nações Unidas (ONU), criada em 1945, na época contava com 58 países signatários, incluindo o Brasil, e foi responsável por elaborar o documento. Foi criada

\begin{tabular}{l|l|l} 
Recebido em: 25/03/2019 & Aceito em: 30/04/2019 & Pg. 50 - 73
\end{tabular}




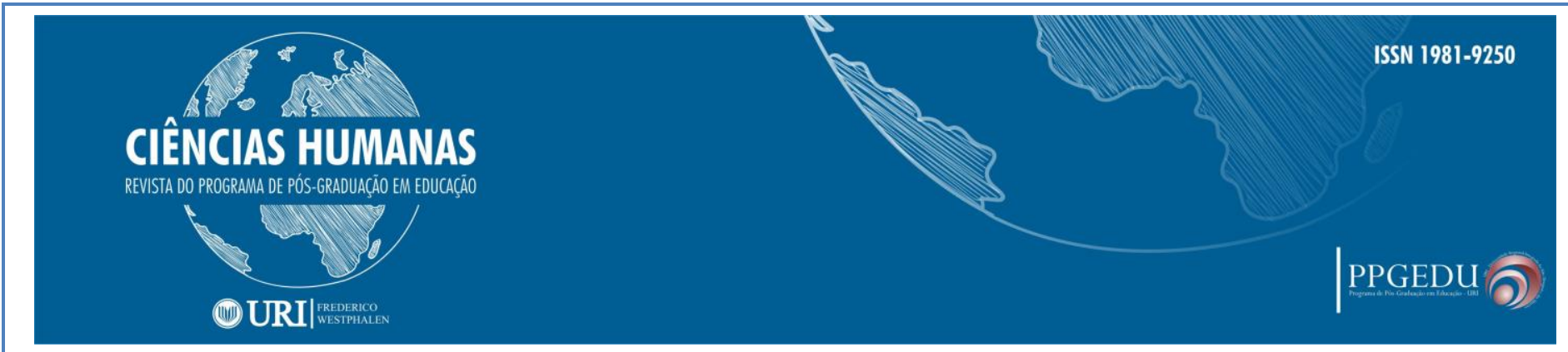

uma comissão de Direitos Humanos presidida pela viúva do presidente americano Franklin D. Roosevelt, Eleanor Roosevelt, com membros de oito países. Em 1947, a comissão criou um esboço preliminar do documento e, em 10 de dezembro de 1948, a Declaração Universal foi aprovada, exprimindo o desejo dos povos em garantir a dignidade humana e a manutenção da paz.

A Declaração Universal já foi traduzida para mais de 500 idiomas, se tornando um marco na defesa da pessoa humana em todo o mundo ${ }^{8}$. Nos trinta artigos que fazem parte do documento, estão definidos os direitos básicos do ser humano, independente de qualquer condição. Trata-se de um documento emblemático na história dos Direitos Humanos, pois mostrou a necessidade de mudar os rumos até então tomados pela humanidade e proteger o ser humano. Os primeiros artigos da Declaração Universal dizem o seguinte:

Artigo $1^{\circ}$ : Todos os seres humanos nascem livres e iguais em dignidade e em direitos. Dotados de razão e de consciência, devem agir uns para com os outros em espírito de fraternidade. Artigo $2^{\circ}$ : Todos os seres humanos podem invocar os direitos e as liberdades proclamados na presente Declaração, sem distinção alguma, nomeadamente de raça, de cor, de sexo, de língua, de religião, de opinião política ou outra, de origem nacional ou social, de fortuna, de nascimento ou de qualquer outra situação. Além disso, não será feita nenhuma distinção fundada no estatuto político, jurídico ou internacional do país ou do território da naturalidade da pessoa, seja esse país ou território independente, sob tutela, autônomo ou sujeito a alguma limitação de soberania. Artigo $3^{\circ}$ : Todo indivíduo tem direito à vida, à liberdade e à segurança pessoal. Artigo $4^{\circ}$ : Ninguém será mantido em escravatura ou em servidão; a escravatura e o trato dos escravos, sob todas as formas, são proibidos. Artigo $5^{\circ}$ : Ninguém será submetido a tortura nem a penas ou tratamentos cruéis, desumanos ou degradantes (ONU, 2016a, p.1).

Ao contrário da ideia de cidadania, que se afirma no marco das especificidades de cada país, os Direitos Humanos se colocam como "universais"

no sentido de que aquilo que é considerado um direito humano no Brasil, também deverá sê-lo com o mesmo nível de exigência, de respeitabilidade e de garantia em qualquer país do mundo, porque eles não se referem a um membro de uma sociedade política; a um membro de um Estado; eles se referem à pessoa humana na sua universalidade (BENEVIDES, 2017, p. 05).

Tal compreensão ampla dos Direitos Humanos permite chegar a uma definição igualmente ampla, que engloba um conjunto de direitos necessários a garantia da

\footnotetext{
${ }^{8}$ Após a Declaração Universal, outros protocolos internacionais foram pactuados voltados a proteção e promoção dos Direitos Humanos, tais como: Convenção relativa à Luta contra a Discriminação no Campo do Ensino (1960); Convenção Internacional sobre a Eliminação de todas as Formas de Discriminação Racial (1966); Pacto Internacional Relativo aos Direitos Econômicos, Sociais e Culturais (1966); Pacto Internacional Relativo aos Direitos Civis e Políticos (1966); Convenção sobre a Eliminação de Todas as Formas de Discriminação contra a Mulher (1979); Convenção sobre os Direitos da Criança (1989); A Convenção para proteção e promoção da diversidade de expressões culturais (2005), entre outros.
}

\begin{tabular}{l|l|r} 
Recebido em: 25/03/2019 & Aceito em: 30/04/2019 & Pg. 50 - 73
\end{tabular}




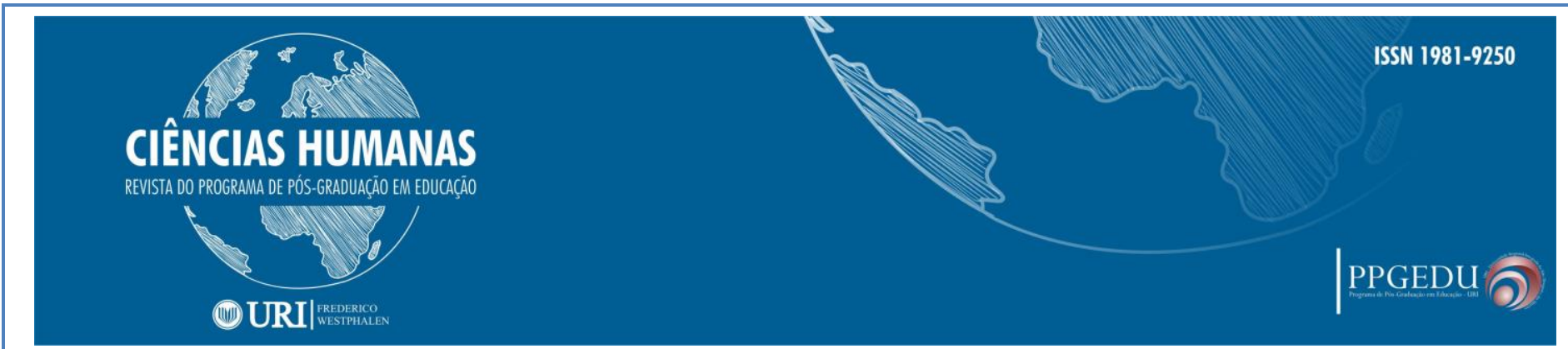

dignidade aos seres humanos, enquanto prerrogativas básicas voltadas a dignidade, liberdade e igualdade. O direito a ter Direitos Humanos está assentado na condição de pertencimento a humanidade e de existência humana objetiva, independente de outras condições, tais como classe, raça/etnia, gênero, idade, nacionalidade, religião, ideologia, aparência e essência. Partindo do reconhecimento às diferenças, os Direitos Humanos objetivam uma igualdade na diversidade, considerando as especificidades e as diferenças individuais. O conceito de equidade pode ser utilizado para traduzir esta relação entre igualdade e diferença ou unidade na diversidade, pois sugere a busca pela igualdade considerando as diferenças, coesão e/ou união, considerando a heterogeneidade que é própria da condição humana. A equidade, nestes termos, está diretamente ligada à noção de justiça e igualdade, que busca contemplar as necessidades de acordo com as especificidades, ou seja, considerando a diversidade, o que a deixa justa.

É importante indicar que os Direitos Humanos possuem uma dimensão contraditória, num primeiro sentido em que é campo de disputa entre Estado e elite, de um lado, e classe trabalhadora, de outro. Num segundo sentido, a dimensão contraditória dos Direitos Humanos se manifesta na contradição ou descompasso entre o arcabouço jurídico-político que lhe dá sustentação e sua plena, ampla e objetiva efetivação. No que se refere ao campo de disputas históricas que envolvem os Direitos Humanos, é possível observar que eles foram apropriados por forças populares e/ou conservadoras em diferentes contextos, dependendo do conjunto de correlações de força historicamente determinadas. Para Baxi (2007, p.240), os Direitos Humanos devem ser vistos com cautela, pois seu discurso

\footnotetext{
é hegemonicamente ocidental; a tradição clássica liberal de direitos e justiça carrega consigo o legado do pecado original: na melhor das hipóteses, essas tradições são óticas para justificar/reciclar o colonialismo; durante e após a guerra fria, a diplomacia dos Direitos Humanos tem sido cumplice das piores violações dos Direitos Humanos; o modelo clássico de Direitos Humanos divulgou uma ideologia de individualismo possessivo de mercado, em que os Direitos Humanos se tornaram direitos do homo economicus.
}

Neste sentido, as múltiplas faces dos Direitos Humanos compõe seu aspecto contraditório faz com que sejam tensionados por diferentes interesses, constituindo-se em arena de luta por projetos distintos. Davidson e Weekley (2003) argumentam que os Direitos Humanos, historicamente, foram utilizados tanto para manter o "governo das leis", como justificativa para o Estado manter seu domínio, quanto para questioná-lo, uma vez que foram apropriados por "forças políticas populares". Inspirados por Gramsci, os autores mostram que o "senso comum" e o "bom senso" estão ancorados na práxis cotidiana, no processo de lutas pela hegemonia, lugar por excelência para se construir uma perspectiva de Direitos Humanos "a-partir-de-baixo", isto é, a partir da

\begin{tabular}{l|l|l} 
Recebido em: 25/03/2019 & Aceito em: 30/04/2019 & Pg. 50 - 73
\end{tabular}


perspectiva das classes populares e subalternas.

A partir deste reconhecimento, é possível entender os Direitos Humanos também como alternativa de luta da classe trabalhadora, estratégia fundamental no processo de disputa pela hegemonia e construção de outro "bloco histórico" de unificação cultural e política, tal como indicado por Gramsci (2002). Em outras palavras, os Direitos Humanos "devem ser entendidos numa perspectiva sócio histórica submetidos às tensões sócio-político-culturais na disputa entre projetos societários distintos" (SANTOS, 2002, p. 38). Neste contexto, é importante a edificação de possibilidades que potencializem a construção dos Direitos Humanos sob a ótica dos marginalizados.

O segundo sentido em que aqui se aponta a dimensão contraditória dos Direitos Humanos está assentado no fato em que o estatuto jurídico dos Direitos Humanos não tem garantido sua aplicação em termos objetivos. Se, por um lado, há reconhecidamente um avanço no ponto de vista do ordenamento jurídico-político no conjunto de declarações e pactos mundiais, que garantem "direitos no papel”, por outro, o desafio que se impõe é concretizar tais direitos em ações, políticas, programas e projetos pelos Estados, principalmente, mas também por instituições, organizações, corporações e grupos econômicos, nos diferentes países. Sua objetivação, portanto, tem implicado numa vigília constante e uma atuação no campo político por parte de instituições e lideranças mundiais, nas últimas décadas, como o importante papel desempenhado por Martin Luther King, Nelson Mandela, Zilda Arns, Malala Yousafzai, entre outros. Dentre as organizações da sociedade civil que tem contribuído na luta pelos Direitos Humanos, podemos citar a Anistia Internacional, o Fundo das Nações Unidas para a Infância, a Human Rights Watch, o programa Médico Sem Fronteiras, entre outros.

Além disso, no limite, a efetivação ampla e plena dos Direitos Humanos só seria possível com uma transformação social, econômica e política radical, visto que a formalização de Direitos Humanos no contexto da sociedade capitalista estão, contraditoriamente, esbarrando na ordem do capital que produz e reproduz desigualdades, exclusão, violências e violações de direitos ao redor do globo. Este ponto é particularmente desafiador para os Direitos Humanos, pois está consubstanciado pelo papel de descortinar essa contradição e a origem das desigualdades, ao mesmo tempo em que aponta alternativas de transformação e objetivação dos direitos que asseguram a dignidade humana de forma ampla. É nesse sentido que Frigotto (2009) argumenta que é preciso avançar rumo a uma "igualdade substantiva" que implique, necessariamente, a transformação da atual dinâmica societária.

Os Direitos Humanos estão intimamente articulados ao quadro mais geral de desigualdades sociais, ficando notoriamente fragilizados em função do contexto de agudização da pobreza e exclusão social que se colocam na sociedade capitalista atual. É importante aqui ponderar, que a análise dos Direitos Humanos relacionados a uma leitura histórico-crítica da sociedade, ancorando-os com questões de natureza macro, é

\begin{tabular}{l|l|l} 
Recebido em: 25/03/2019 & Aceito em: 30/04/2019 & Pg. 50 - 73
\end{tabular}




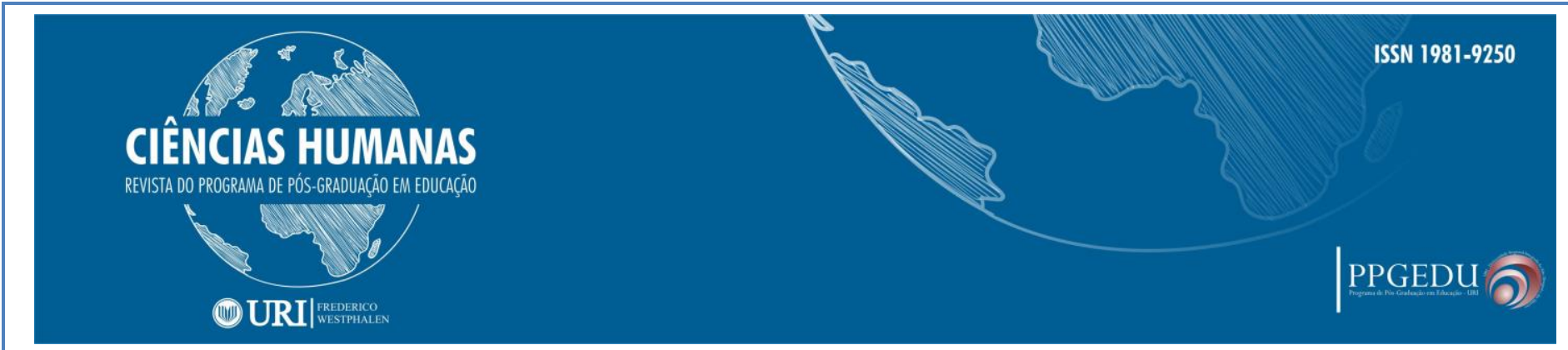

fundamental para possibilitar uma visão crítica e totalizante da sociedade e dos Direitos Humanos, no sentido de entender as relações sociais em sua totalidade, possibilitando o desvelamento das causas das desigualdades. Não obstante os avanços alcançados até o momento, nestes 70 anos da Declaração Universal, muitos desafios ainda se colocam para os Direitos Humanos nos nossos dias. É preciso intensificar a luta de maneira articulada e, nesse sentido, fortalecer projetos sociais democráticos é de suma importância. É preciso, pois, ponderar sobre a configuração e o papel dos Estados que podem contribuir para fortalecer ou obstaculizar os Direitos Humanos.

\section{DIREITOS HUMANOS, DEMOCRACIA E ESTADO: UMA ARTICULAÇÃO NECESSÁRIA!}

A proteção e materialização dos Direitos Humanos pressupõem uma conjuntura sócio-política democrática. Sem democracia não pode haver realização plena dos Direitos Humanos e vice versa. Poder-se-ia afirmar que a democracia está para os Direitos Humanos assim como os Direitos Humanos estão para a democracia. Isto, pois em regimes totalitários e/ou ditatoriais muitos direitos são violados, tais como a liberdade de expressão e o direito de ir e vir; também são utilizados métodos contrários a proteção e a dignidade humana, tais como torturas e prisões arbitrárias. Por outro lado, mesmo sociedades que se afirmam democráticas, utilizam-se de mecanismos que, sob a capa da legalidade, fragilizam a democracia e a colocam em risco. Tais sociedades incorrem em graves violações aos Direitos Humanos, sendo um exemplo emblemático o Apartheid na África do Sul, regime de segregação social e racial legalmente instituído que perdurou de 1948 até 1994 e teve Nelson Mandela como seu principal líder de oposição.

Deste modo, corrobora-se com a visão de que a luta pela democracia passou a ser um dos grandes objetivos da humanidade, pois é um regime de governo que, não obstante suas limitações, abre o cenário político para a contraposição de projetos de sociedade, para a disputa pelo direcionamento do ordenamento jurídico-político e pela democratização do fundo público, o que possibilita a luta por direitos em prol das classes e segmentos historicamente marginalizados, excluídos e oprimidos. Arriscar-seia afirmar que, fora de um regime democrático - entendido no sentido da vontade geral colocada por Rousseau (1978) na obra "Do contrato Social", de 1762, em que o poder emana do povo -, vozes discordantes são mais facilmente silenciadas e violações aos Direitos Humanos ocorrem sobremaneira. Para Santos (2006, p. 01), a relação entre democracia e Direitos Humanos é fundamental, pois "a democracia é entendida como um regime político que melhor protege e promove os direitos humanos. É definida ainda, como regime fundado na soberania popular, na separação e desconcentração de poderes, com pleno respeito aos direitos humanos". Há, portanto, a necessidade de um

\begin{tabular}{l|l|l} 
Rev. Ciências Humanas & Frederico Westphalen, RS & Jan./abr. 2019
\end{tabular}

\begin{tabular}{l|l|l} 
Recebido em: 25/03/2019 & Aceito em: 30/04/2019 & Pg. 50 - 73
\end{tabular}




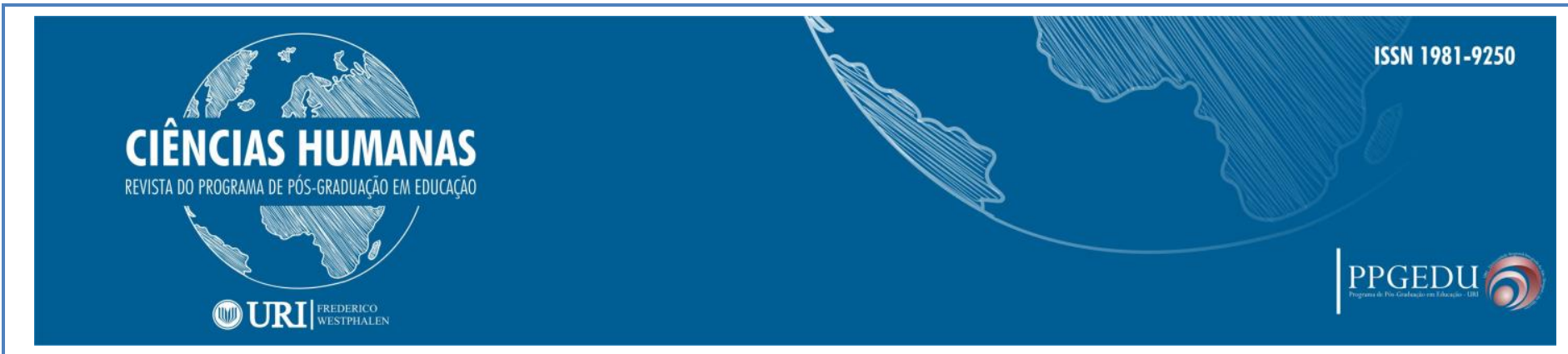

debate sobre democracia na interface com os Direitos Humanos, visto que

o princípio de supremacia dos Direitos Humanos constitui elemento essencial à democracia. É difícil imaginar uma definição de democracia que não esteja atrelada aos direitos civis e políticos fundamentais. Uma das conexões mais cruciais entre Direitos Humanos e democracia é a prevenção contra o exercício injusto da autoridade, com a participação ativa da sociedade (RIZZINI, 2009, p. 81).

Buscando identificar os princípios da democracia e sua relação com os Direitos Humanos, O’Brien (2007, p.610) afirma que "a participação é o principal papel dos cidadãos em uma democracia" e indica que "em sociedades democráticas todas as pessoas devem ser iguais". Além disso, elenca como alicerces das democracias elementos como a participação do cidadão, igualdade, tolerância política, transparência, eleições periódicas e direitos humanos. O’Brien (2007, p.611) também menciona a importância de países possuírem uma "carta de direitos" para "proteger as pessoas contra abusos de poder" com uma "lista de direitos e liberdades garantidos a todas as pessoas". Na relação entre democracia e Direitos Humanos, o autor argumenta que "todas as democracias lutam para respeitar e proteger os Direitos Humanos dos cidadãos. Direitos humanos significam aqueles valores que refletem o respeito pela vida e pela dignidade humanas. A democracia enfatiza o valor de cada ser humano" (O’BRIEN, 2007, p.612).

Significa dizer que a democracia é a "construção coletiva do espaço público" (COUTINHO, 2000, p. 50), que deveria se traduzir, também, em "bens sociais" consubstanciados em direitos de cidadania. Nisso, temos o estabelecimento de uma relação entre democracia e cidadania, pois esta última está fundamentada no exercício de deveres e de direitos historicamente conquistados. "Nesse sentido pode-se afirmar que, na sua acepção mais ampla, cidadania é a expressão concreta do exercício da democracia” (PINSKY, 2003, p.10). Esta perspectiva de democracia não a restringe ao sistema político e ao exercício dos direitos políticos, abarcando também a democratização dos direitos sociais.

Chauí (1993, p.186) contribui com o debate enfatizando que a "democracia social e democracia política não podem ser separadas, sob pena de se tornarem soluções parciais". Em sua totalidade, a democracia implica na existência de condições objetivas para o exercício da soberania dos cidadãos, quando articulados politicamente e com caminhos abertos para sua participação na tomada das decisões sociais e econômicas. Para Chauí (1993), a luta pela democracia é absolutamente necessária para a humanidade, pois carrega um potencial emancipatório. Coutinho (2000, p.50) vai no mesmo sentindo refletindo que

\begin{tabular}{l|l|l} 
Recebido em: 25/03/2019 & Aceito em: 30/04/2019 & Pg. 50 - 73
\end{tabular}




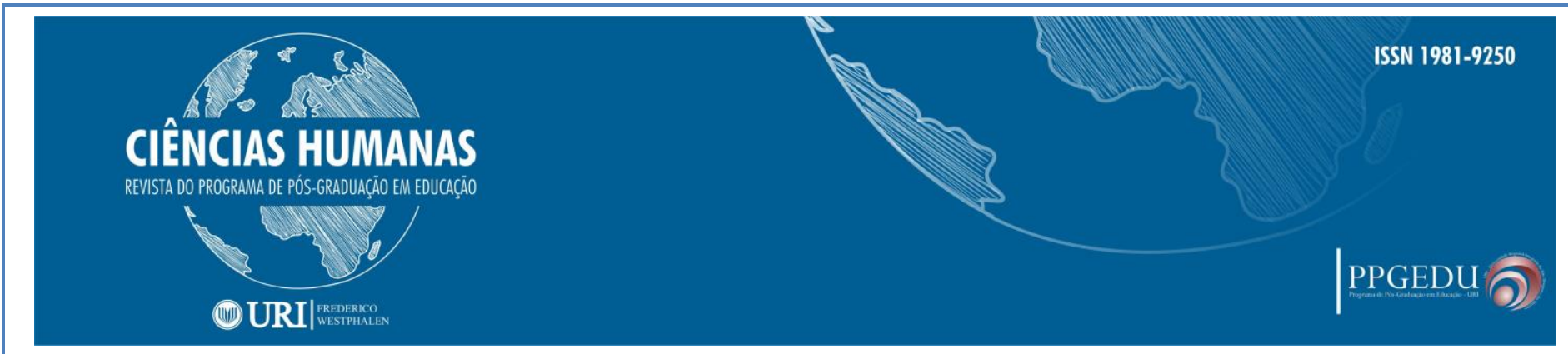

democracia é sinônimo [de] soberania popular, ou seja: podemos defini-la como a presença efetiva das condições sociais e institucionais que possibilitam ao conjunto dos cidadãos a participação ativa na formação do governo e, em consequência, no controle da vida social.

Para Santos (2006), deve-se buscar uma articulação entre "democracia política" e "democracia social" que implique na busca por igualdade, principalmente do ponto de vista econômico. E esta busca deve ser realizada tendo como horizonte a soberania popular e o zelo pelos Direitos Humanos. Não uma igualdade abstrata, mas uma igualdade que se traduza em políticas igualitárias fortalecedoras da cidadania. Para Santos (2006), há um declínio da cidadania e da democracia por conta dos interesses expressos na geopolítica global atual, em que a globalização ocorre desigualmente e os países "periféricos" são subalternizados neste processo, especialmente contribuindo para maximizar o capital financeiro em detrimento da concretização da cidadania. Por isso, torna-se necessário construir outra forma de relação entre os povos, uma "democracia cosmopolita" que possibilite um desenvolvimento que afirme os Direitos Humanos. No caso dos países Latino Americanos, ao que se inclui o Brasil, é preciso avançar rumo a uma democracia que garanta a participação política de todos os cidadãos e a universalização dos direitos sociais.

A despeito da Declaração Universal dos Direitos Humanos de 1948 já estar em vigor, diversos países da latino-américa foram dominados por regimes ditatoriais na segunda metade do século $\mathrm{XX}$, os quais tinham o avanço comunista no continente americano como principal adversário, especialmente a partir da Revolução Cubana de 1959 que culminou com a ascensão do governo comunista de Fidel Castro. Cabe ressaltar que, neste período, o mundo estava no contexto da Guerra Fria, dividido política, econômica e ideologicamente entre capitalismo e comunismo, entre Estados Unidos e União Soviética, cuja disputa colocou o planeta sob a ameaça de uma batalha nuclear, se estendendo por 40 anos, até 1991, logo após a queda do Muro de Berlim, que ocorreu em 1989.

$\mathrm{Na}$ América Latina, grupos conservadores mobilizaram-se com apoio de movimentos civis ligados a classe média e ao empresariado local e, estritamente vinculados aos interesses capitalistas norte-americanos, culminando com uma sucessão de golpes de Estado e com a instituição de governos autocráticos militares, como na Guatemala em 1954, seguido de Argentina em 1962, Brasil em 1964 e Peru em 1968. Tais regimes se caracterizaram pela concentração de poder e por uma forte repressão aos que a eles se opuseram. Especificamente no Brasil, a ditadura militar se utilizou dos Atos Institucionais ${ }^{9}$, cujo mais severo foi o Ato Institucional $n^{\circ} 5$ (AI5), de 1968, os

\footnotetext{
${ }^{9}$ Os militares utilizavam os Atos Institucionais como mecanismo de imposição de decisões favoráveis ao regime. Dos 17 (dezessete) Atos Institucionais promulgados, um dos mais lembrados é o AI5, de 1968, que concedeu poderes ilimitados ao presidente da república e proibiu manifestações. Além disso, tudo o que era considerado contrário à segurança nacional era criminalizado ou censurado.
}

\begin{tabular}{l|l|l}
\hline Rev. Ciências Humanas & Frederico Westphalen, RS & Jan./abr. 2019 \\
\hline
\end{tabular}

\begin{tabular}{l|l|l} 
Recebido em: 25/03/2019 & Aceito em: 30/04/2019 & Pg. 50 - 73
\end{tabular}




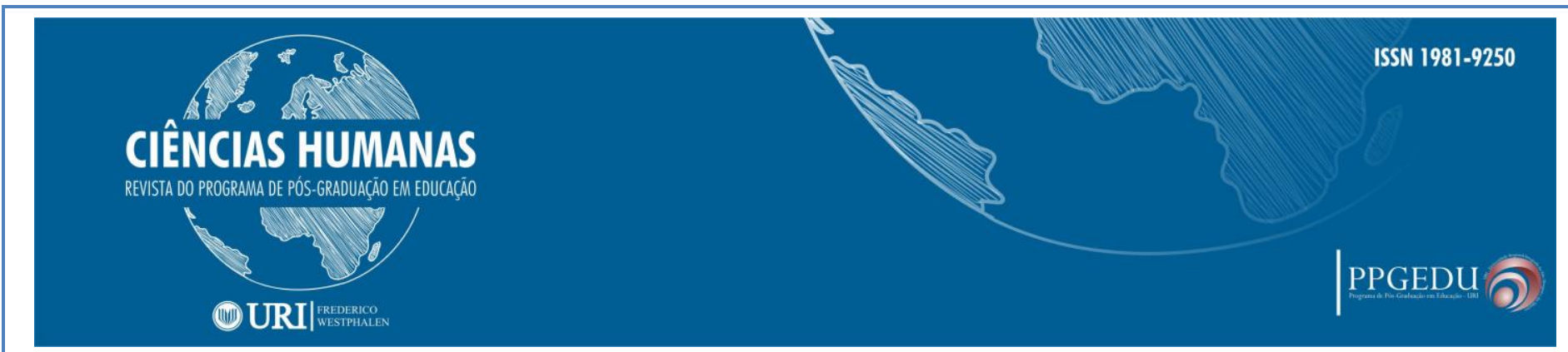

quais permitiam a censura, a criminalização, a perseguição política, a supressão de direitos constitucionais, proibição de manifestações, entre outros atos antidemocráticos.

Não obstante as particularidades dos governos militares latino-americanos e dos lentos processos de transição democráticas que se desenrolaram, entre os anos 1979 e 1990; e, associados a recessão econômica que atingiu a América Latina no contexto da crise mundial do capital que ocorreu neste período, pode-se afirmar que os movimentos de redemocratização foram marcados por intensas mobilizações de oposição e resistência democrática, rearticulação dos sindicatos e partidos políticos, movimentos de trabalhadores e de estudantes, mobilizações populares na cidade e no campo, que denunciavam a violência, o reconhecimento de mortos, desaparecidos e perseguidos, e emanavam por democracia. É relevante indicar que, entre os anos 1980 e 1990, com a abertura política, diversos movimentos sociais passam a levantar a bandeira dos Direitos Humanos em defesa da igualdade racial, de gênero, entre outras.

Mesmo com o término das ditaduras nos países latino-americanos, a inauguração de processos de institucionalização democrática não resultou numa socialização da política e "em nenhuma socialização do poder político significativa e expressiva" (NETTO, 2009, p.06). Para Netto (2009), é difícil pensar em socialização do poder político sob a égide do capital, pois os interesses da classe dominante se sobrepõem. Ao tratar da relação entre democracia e Direitos Humanos na América Latina, Netto (2009) enfatiza que o continente latino-americano ainda precisa avançar na direção de uma democratização substantiva das diferentes sociedades juntamente com a luta contra a exploração econômica, o que implica no questionamento ao status quo. Frigotto (2009) aponta quatro heranças históricas do continente latino-americano que fragilizaram a democracia e os Direitos Humanos na região, quais sejam: a escravidão e colonização do continente que culminaram no genocídio dos povos indígenas e no trato desumano dos escravos; o capitalismo dependente que se desenvolveu no continente e que só acentuou o processo de exploração; as ditaduras civil militares; e, a herança neoliberal que significou uma "ditadura do mercado" com perdas de direitos da classe trabalhadora.

É neste contexto que os Direitos Humanos se inserem e precisam ser tematizados, explicitando que, não obstante a importância dos direitos civis, políticos, culturais e ambientais, a defesa dos Direitos Humanos está intrinsicamente articulada com a defesa de direitos sociais - os quais são permeados pelos direitos econômicos em uma sociedade capitalista -, uma vez que estes carecem de ser democratizados para que o ideal de dignidade humana seja alcançado, especialmente, pelas populações marginalizadas. Em última instância, poder-se-ia argumentar que, sem a garantia de direitos sociais básicos, tais como alimentação e saúde, não há realização dos Direitos Humanos; e que para sua plenitude é imprescindível o atendimento ao conjunto de necessidades materiais e imateriais do que se entende por dignidade humana no

\begin{tabular}{l|l|l} 
Recebido em: 25/03/2019 & Aceito em: 30/04/2019 & Pg. 50 - 73
\end{tabular}




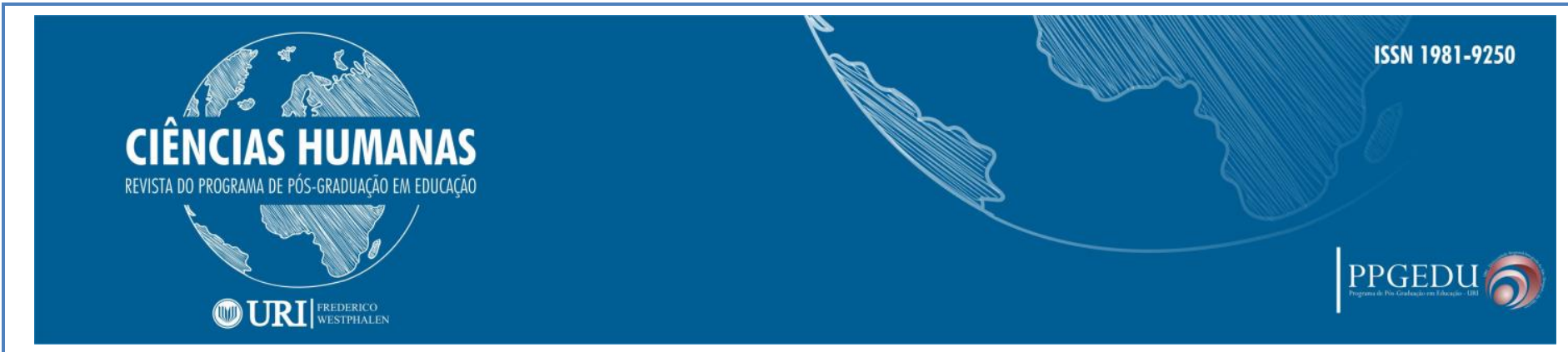

contexto do desenvolvimento civilizatório atingido pela humanidade no presente momento. Tal reflexão está articulada a concepção dos Direitos Humanos vinculada ao enfrentamento e a superação das desigualdades sociais, tal como discutido na sessão anterior. Considera-se, portanto, que a concretização dos Direitos Humanos é uma questão de natureza política e democrática que vai implicar na socialização efetiva do poder político e na democratização da riqueza socialmente produzida. Para tanto, há que reivindicar a atuação do Estado.

Parte-se do pressuposto de que os Direitos Humanos e o conjunto de atos necessários à sua efetivação, demandam ações articuladas entre várias esferas, todavia dependem sobremaneira do Estado para se concretizar. A configuração estatal é absolutamente necessária para avanços no campo dos Direitos Humanos, assim como se constituem em elemento determinante nas situações de retrocessos e violações destes direitos.

O conceito de Estado ampliado de Gramsci diferencia duas esferas em seu interior, "sociedade política + sociedade civil, isto é, hegemonia encouraçada na coerção" (GRAMSCI, 2002, p. 244). O pensador italiano percebeu que nas sociedades modernas ocidentais, coexistem sociedade civil e sociedade política na luta pela hegemonia, formando o que denominou de "Estado ampliado". A "sociedade política" apresenta-se como o Estado em sentido estrito ou Estado-coerção, é o lugar no qual se processa a hegemonia mediante estratégia de repressão e violência. Já a "sociedade civil" é lugar em que se difundem e se formam as ideologias, terreno da construção da hegemonia pelo consenso. Sindicatos, igreja, escolas, partidos políticos e meios de comunicação, fazem parte do que Gramsci chamou de "aparelhos privados de hegemonia", ou seja, organismos de atuação política e cultural que compõem a sociedade civil e que operam na formação de consensos, não fazendo uso da repressão. Estes organismos de adesão voluntária se afastam materialmente do Estado, tendo um caráter "privado", isto é, detêm certa autonomia em relação ao Estado em sentido estrito. Nessa direção, a apropriação dos Direitos Humanos pelos "aparelhos privados de hegemonia" vinculados aos grupos populares torna-se fulcral, pois permitiria, entre outras coisas, o questionamento da própria lógica estatal, isto é, o Estado em sentido restrito.

Mesmo que se reconheça o papel da sociedade civil, é preciso ponderar a existência de interesses antagônicos dos agentes que compõem a sociedade civil. A atuação de sujeitos políticos vinculados as demandas de grupos populares é condição imprescindível para o fortalecimento da democracia, assim como a ampliação dos canais institucionalizados de participação e diálogo são fundamentais dentro da dinâmica de funcionamento de um "Estado ampliado" que se pretende democrático. Nos termos e sentidos empregados por Chauí (1993), para além de uma "cidadania passiva" oriunda de decisões arbitrárias do Estado e assentadas na perspectiva do favor e da tutela que trata os direitos como concessão do Estado, é preciso fortalecer uma

\begin{tabular}{l|l|l} 
Recebido em: 25/03/2019 & Aceito em: 30/04/2019 & Pg. 50 - 73
\end{tabular}




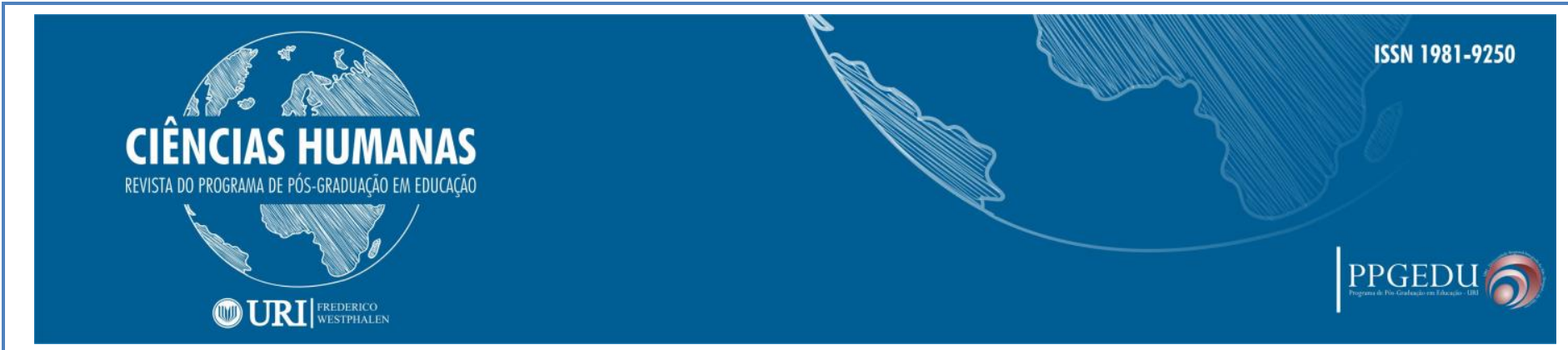

perspectiva de "cidadania ativa" que sublinhe as demandas da sociedade civil tanto criando espaços efetivos de participação política quanto entendendo o cidadão como criador e portador de direitos e deveres.

É importante lembrar que a Declaração Universal dos Direitos Humanos (Declaração Universal) reivindica o papel dos Estados nacionais, indicando que "os Estados membros se comprometeram a promover, em cooperação com a ONU, o respeito universal e efetivo dos direitos do Homem e das liberdades fundamentais" (ONU, 2016a, p.1). Neste sentido, pode-se indicar que o chamado Estado de Bem-Estar Social ou Welfare State é expressão de experiências em torno da construção de um sistema de garantia de direitos que coadunam com a ideia dos Direitos Humanos aqui desenvolvida. A perspectiva de um Estado interventor emerge após a crise de 1929, quando o capitalismo buscou se reestruturar visando a retomada da lucratividade, momento em que as funções e estrutura do Estado são alteradas na direção de sua intervenção nas relações sociais. A principal influência foram as teorias do economista John M. Keynes, na obra intitulada "A teoria geral do emprego, do juro e da moeda", de 1936. Ao se opor a concepção liberal da "mão invisível” do mercado, Keynes indica o papel do Estado como indispensável agente regulador da economia, visando aumentar o investimento público estatal de forma e gerar demanda efetiva e o pleno emprego.

Não é interesse aqui aprofundar o debate histórico e teórico acerca do Estado de Bem-Estar Social, todavia para se pensar os Direitos Humanos, é relevante indicar que, a partir do pós-segunda guerra, independentemente das condições e do grau em que o Estado de Bem-estar se desenvolveu em diferentes países, as concepções e experiências deste tipo de Estado estiveram voltadas a progressiva intervenção estatal nas relações sociais, mediante a implantação de medidas e políticas de proteção aos pobres e aos trabalhadores, baseando-se em uma noção de direito social, como forma de garantir a reprodução social. Por outro lado, é importante ressaltar que o Estado de Bem-Estar Social não pode ser concebido como uma esfera autonomizada da estrutura capitalista e intocada pela luta de classes, ou contrário, é permeado pela correlação de forças e interesses sociais distintos.

Após o período de redemocratização, vários países latino-americanos, incluindo o Brasil, adotaram a política neoliberal que, na contramão do Estado interventor, entre outras medidas, visou reduzir o tamanho do Estado, retomando o ideal liberal que maximiza o livre mercado. O Consenso de Washington ${ }^{10}$, de 1989, assinalou recomendações de reestruturação produtiva, concentrando medidas de reforma estrutural aos países capitalistas como desregulamentação dos mercados, abertura comercial e financeira, privatização do público e redução do tamanho e do papel do

\footnotetext{
${ }^{10}$ Consenso de Washington é o nome dado ao encontro ocorrido na capital dos Estados Unidos, no ano de 1989, no qual estiveram presentes diversos economistas latino-americanos liberais, funcionários do Fundo Monetário Internacional (FMI), Banco Mundial, Banco Interamericano de Desenvolvimento (BID) e do governo norteamericano. Seu objetivo foi indicar medidas de restruturação nos moldes neoliberais aos países latino-americanos.

\begin{tabular}{l|l|l}
\hline Rev. Ciências Humanas & Frederico Westphalen, RS & Jan./abr. 2019 \\
\hline
\end{tabular}

\begin{tabular}{l|l|l} 
Recebido em: 25/03/2019 & Aceito em: 30/04/2019 & Pg. 50 - 73
\end{tabular}
}




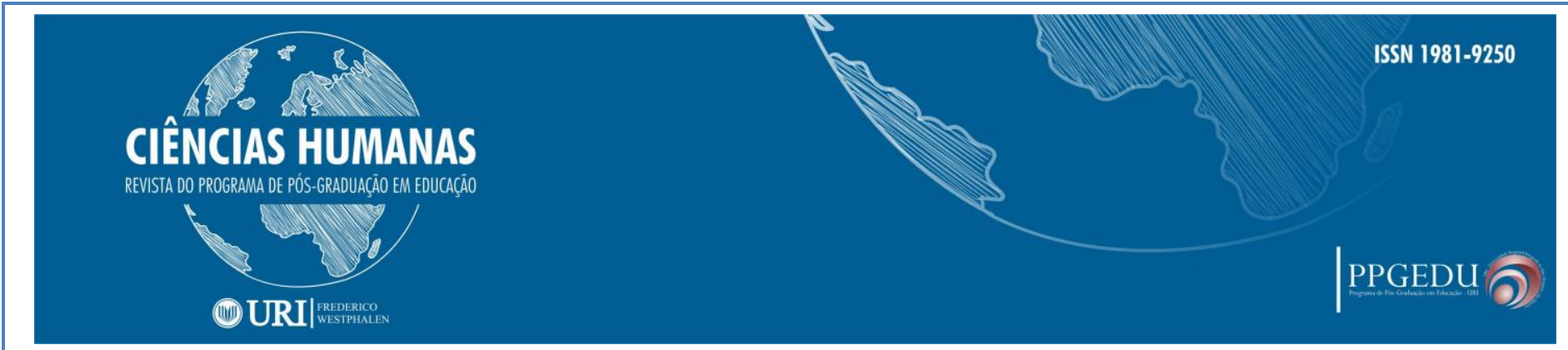

Estado, onde uma menor intervenção do Estado propiciaria uma maior flexibilidade do mercado. No discurso neoliberal, o tamanho e a ineficiência Estado seria responsável pela crise, pelo que ele deveria ser reduzido. Neste sentido, a década de 1990 foi marcada por privatizações e redução dos gastos públicos em áreas sociais básicas. Tais medidas não foram eficazes no enfrentamento ao contexto histórico de desigualdades que marcam o Brasil, ao contrário, contribuíram para aumentar o hiato existente entre ricos e pobres no país, reforçando o capitalismo dependente brasileiro (FERNANDES, 1973), mantendo os privilégios intocados e expropriando direitos. No Brasil, representou um desmantelamento dos direitos proclamados na Constituição de 1988.

Bresser Pereira (1996) foi um dos principais intelectuais do neoliberalismo no Brasil. O diagnóstico indicado por ele é que o país passava por uma crise do Estado, "pela perda de capacidade do Estado de coordenar o sistema econômico de forma complementar ao mercado", ou ainda, uma "crise que se define como uma crise fiscal, como uma crise do modo de intervenção do Estado" (BRESSER PEREIRA, 1996, p.03). Bresser Pereira (1996, p.01) sugere ao Estado um novo papel, "de facilitar que a economia nacional se torne internacionalmente competitiva". Inverte a lógica da intervenção estatal na provisão de direitos substituindo-a pela lógica da prestação de serviços sociais por organizações sociais não estatais e não lucrativas. Tal perspectiva não coaduna com uma gestão pública popular e democrática, imprimindo um caráter privado a gestão serviços sociais, em que o Estado passa a ser regulador e não executor das políticas vinculadas a efetivação dos direitos sociais. Este entendimento invadiu a dinâmica estatal e foi à tônica deste período. O discurso de demonização do público em favorecimento ao privado serviu de base para o sucateamento e retirada de investimentos em áreas cruciais para o combate as desigualdades.

Virando o século XXI, mais precisamente em 2003, a chegada da esquerda ao poder no Brasil com a posse de Luís Inácio Lula da Silva na presidência da república, significou a retomada de um otimismo político das classes populares, pela sinalização de reversão do projeto político da direita. Em seu desenrolar, o governo de Lula foi considerado por muitos intelectuais como moderado ${ }^{11}$, sendo que a política de conciliação de classes já estava colocada na sua "Carta ao Povo Brasileiro" ${ }^{12}$,, no apagar das luzes das eleições, e sinalizou pazes para com as elites e o mercado financeiro. $\mathrm{O}$ governo Lula, de acordo com Sader (2010, p. 27),

\footnotetext{
Manteve alguns elementos das políticas do governo anterior e rejeitou outros, configurando um quadro contraditório. Na sua primeira fase, primaram os elementos de continuidade, mantendo-se um rígido ajuste fiscal [...]. Adotou políticas sociais e política externa claramente inovadoras e, ao mesmo tempo, manteve tanto a política econômico-financeira como a política agrícola
}

\footnotetext{
${ }^{11}$ Por não ter alterado a natureza do poder ou a estrutura do Estado capitalista burguês no Brasil, muitos militantes do PT migraram para outras siglas partidárias mais à esquerda, como PSOL e PSTU.

${ }^{12}$ Apesar da carta ser endereçada ao "povo brasileiro", este documento também significou um recado de Lula para o mercado financeiro, pois buscou neutralizar a desconfiança na situação econômica do país naquele momento.
}

\begin{tabular}{l|l|l}
\hline Rev. Ciências Humanas & Frederico Westphalen, RS & Jan./abr. 2019 \\
\hline
\end{tabular}

\begin{tabular}{l|l|l} 
Recebido em: 25/03/2019 & Aceito em: 30/04/2019 & Pg. 50 - 73
\end{tabular}




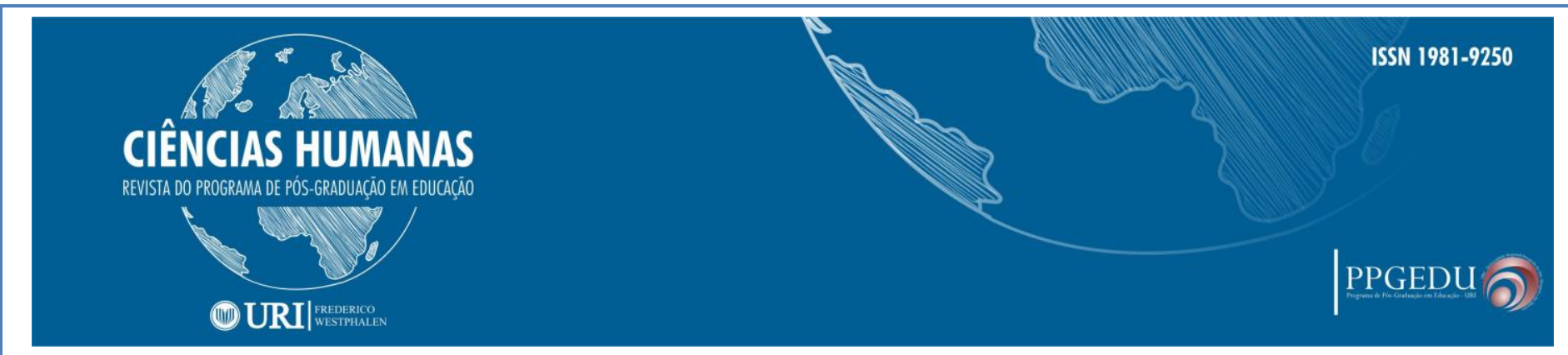

tradicional.

A partir de 2010, o governo da petista Dilma Rousseff manteve os objetivos de manutenção da estabilidade econômica e de erradicação da pobreza. A chegada de uma mulher a presidência no Brasil também significou um marco na luta das mulheres na esfera política ${ }^{13}$. Do ponto de vista dos Direitos Humanos, os governos petistas implementaram diversas medidas de combate a pobreza, sendo seus exponentes o Programa Fome Zero ${ }^{14}$ e o Bolsa Família ${ }^{15}$. Estas políticas foram importantes para a efetivação de direitos básicos, tais como o combate a fome e distribuição de renda, contribuindo para a redução da pobreza no Brasil. Além disso, na área da educação, foram implementadas políticas de cotas que democratizaram o acesso ao nível superior; foram criadas as leis $\mathrm{n}^{\mathrm{o}} 10.639$, de 2003 - que coloca a história e cultura afro-brasileira e africana como conteúdos obrigatórios - e a lei $\mathrm{n}^{\mathrm{o}} 11.645$ de 2008 que orienta incluir no currículo oficial da rede de ensino a obrigatoriedade da temática história e cultura afro-brasileira e indígena.

A tendência colocada pelos governos petistas à política social brasileira do século XXI, baseou-se na lógica de transferência de renda. Considerado por Pfeifer (2014, p.757) como um governo neodesenvolvimentista, nesta modalidade de política social "o acesso aos bens e serviços sociais considerados no âmbito das necessidades humanas e no escopo da cidadania, vem sendo possibilitado não mais pela operacionalização direta do Estado na sua provisão", mas mediados pelos programas de bolsas sociais, que transferem valores monetários para as famílias pobres e lhe dão acesso através da compra de bens e serviços no mercado. "Essa plataforma da política social neodesenvolvimentista, funda um novo Estado, intitulado aqui de Estado mediador consumidor, visto que passa a ser um grande consumidor dos bens e serviços sociais mercantilizados" (PFEIFER, 2014, p.747), acabando por se constituir numa política de consumo de massa que teve importantes rebatimentos do ponto de vista do mercado interno nacional.

\section{PARA ONDE ANDAMOS?}

O histórico brasileiro e de outros países da América Latina evidenciam que o caminho para a consolidação de uma democracia substantiva - entendida no sentido

\footnotetext{
${ }^{13}$ Em uma sociedade patriarcal, como a brasileira, sua vitória democrática expressou, entre outras coisas, uma resposta da sociedade a desigualdade de gênero e, dentro de seus limites, sinalizou mudanças no papel requerido pelas mulheres no mundo contemporâneo.

${ }^{14}$ Foi criado em 2003 e tinha como objetivo garantir a segurança alimentar no Brasil. O programa incluía também o combate à desnutrição a ampliação da alimentação nas escolas.

${ }^{15}$ Criado também em 2003, o Bolsa Família objetivou a transferência de renda para a população mais pobre mediante alguns condicionantes, tais como: manter as crianças e os adolescentes entre 6 e 17 anos com frequência na escola e vacinação em dia.
}

\begin{tabular}{l|l|l}
\hline Rev. Ciências Humanas & Frederico Westphalen, RS & Jan./abr. 2019
\end{tabular}

\begin{tabular}{l|l|l} 
Recebido em: 25/03/2019 & Aceito em: 30/04/2019 & Pg. 50 - 73
\end{tabular}




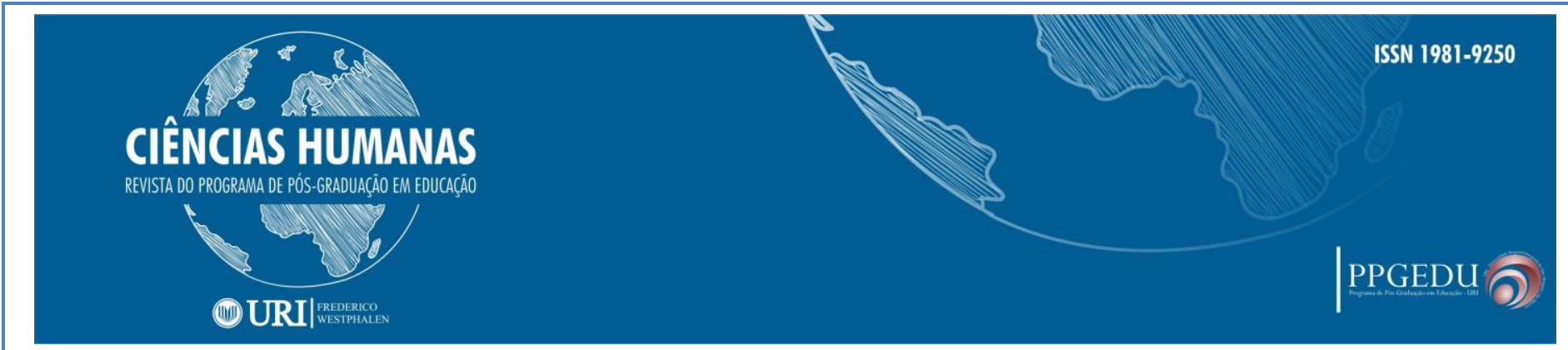

posto por Mészáros (2015) de uma democracia associada a igualdade que contrasta com a concepção de democracia liberal -, ainda é bastante longo e que as desigualdades sociais características destes países constituem um obstáculo para sua realização plena. Assim como em outros países do continente, a "revolução passiva" realizada pela elite brasileira no processo de modernização do país não significou avanço expressivo no campo dos direitos sociais. O capitalismo dependente, tal como analisado por Fernandes (1973), manteve os privilégios e não possibilitou a criação de um sistema de proteção social capaz de sanar a dívida social histórica.

Após o ciclo de superação dos regimes militares na América Latina, as democracias do continente ainda não podem ser consideradas estáveis, ao contrário, são sucessivamente ameaçadas. No início do ano 2000, houve golpe no Equador e tentativa de golpe no Paraguai. Em 2001, "ocorreram quedas de presidente na Argentina, na Venezuela, na Bolívia, no Haiti e novamente no Equador” (BOTELHO, 2019, p.6) Num contexto de crise econômica e de crise de credibilidade de partidos e políticos, a articulação entre judiciário, imprensa e os blocos de oposição - com o apoio de setores reacionários e conservadores da população, especialmente as classes médias -, culminou com golpes de Estado, que destituíram presidentes democraticamente eleitos, como Manuel Zelaya em Honduras, em 2009; no Paraguai Fernando Lugo, em 2012; no Brasil Dilma Rousseff, em 2016. Löwy (2018, p.04), chamou este processo de "o ódio à democracia". Movimentos contrários aos golpes e favoráveis à democracia foram severamente reprimidos em manifestações com bombas, tiros, gás e cassetetes.

O contexto latino-americano e brasileiro atual reitera a necessidade de se avançar rumo a uma democratização plena dos Estados e dos Direitos Humanos no continente, objetivando recuperar a dignidade de seus povos. Isso significa que o "Estado Democrático de Direito" deve se orientar pela "soberania popular" e buscar efetivar a cidadania, condição imprescindível para se vislumbrar um horizonte emancipatório. Esta tarefa implica uma atuação que envolva, necessariamente, a batalha "no campo das ideias e da política" (FRIGOTTO, 2009, p. 21). Para tanto, "por certo, o ponto hoje crucial e mais complexo é desenvolver as condições subjetivas, isto é, que uma grande multidão, como assinala Gramsci, perceba essa necessidade histórica e se organize para realizá-la" (FRIGOTTO, 2009, p. 22). Nessa empreitada, Frigotto (2009) observa que a escola e os meios de comunicação de massa são fundamentais no conjunto dos elementos constituidores da cultura em disputa, e que precisam ser mobilizados para fortalecer um projeto societário que possibilite a efetivação plena dos Direitos Humanos. Nessa empreitada, a debate acerca da cultura em Direitos Humanos se coloca como elemento de relevo. Uma cultura que se traduza em outro tipo de sociabilidade, alicerçada em valores como tolerância e paz. 


\section{REFERÊNCIAS}

ANISTIA INTERNACIONAL. Informe 2017/2018: O estado dos direitos humanos no mundo. Disponível em < https://anistia.org.br/wp-

content/uploads/2018/02/informe2017-18-online1.pdf>. Acesso em 30 nov. 2018.

ANTUNES, Ricardo. De Vargas a Lula: Caminhos e Descaminhos da legislação Trabalhista no Brasil. Revista Pegada, São Paulo, v.7, n.2, nov. 2006.

BAXI, Upendra. Educação em Direitos Humanos: Promessa do Terceiro Milênio? In: ANDREOPOULOS, George. CLAUDE, Richard P. Educação em Direitos Humanos para o século XXI. São Paulo: EDUSP, Núcleo de Estudos da Violência, 2007.

BENEVIDES, Maria Victoria. Cidadania e Direitos Humanos. Cadernos de Pesquisa, n. 104, 1998. Disponível em

<http://publicacoes.fcc.org.br/ojs/index.php/cp/article/view/715/731>. Acesso em 20 $\operatorname{mar} 2017$.

BOTELHO, Amoroso. A instabilidade democrática na América Latina do século XXI: Os casos da Argentina e da Venezuela. Disponível em:

$<$ http://www.uel.br/grupo-

pesquisa/gepal/primeirosimposio/completos/joaocarlosamorosobotelho.pdf > . Acesso em 14 fev. 2019.

BRASIL. Constituição Federal do Brasil de 1988. Disponível em http://www.planalto.gov.br/ccivil_03/Constituicao/Constituicao37.htm. Acesso em set. $2016 \mathrm{a}$.

BRESSER PEREIRA, L. C. Da administração pública burocrática à gerencial. Revista do Serviço Público, 47(1) janeiro-abril, 1996.

CHAUÍ. Marilena. Cultura e Democracia: o discurso competente e outras falas. $6^{\text {a }}$ ed. São Paulo: Cortez, 1993.

COSTA, Lucia Cortes. Os impasses do Estado capitalista: uma análise sobre a reforma do Estado no Brasil. Ponta Grossa: UEPG; São Paulo: Cortez, 2006.

COUTINHO, C. N. Contra a Corrente: ensaios sobre democracia e socialismo. São Paulo: Cortez, 2000.

DAVIDSON, Alastair e WEEKLEY, Kathleen. Gramsci e os direitos do homem. In: COUTINHO, Carlos Nelson e TEIXEIRA, Andréa de Paula (Orgs.). Ler Gramsci, entender a realidade. Rio de Janeiro: Civilização Brasileira, 2003. p.83-97.

FERNANDES, Florestan. Capitalismo dependente e classes sociais na América Latina. Rio de Janeiro: Zahar, 1973.

\begin{tabular}{l|l|l} 
Recebido em: 25/03/2019 & Aceito em: 30/04/2019 & Pg. 50 - 73
\end{tabular}


FRIGOTTO, Gaudêncio. Direitos humanos, democracia e educação na contemporaneidade. In: FREIRE, Silene (Org.) Direitos Humanos e Questão Social na América Latina. Rio de Janeiro: Gamma, 2009.

GRAMSCI, Antonio. Cadernos do cárcere. Vol. 3. . Edição e tradução de Carlos Nelson Coutinho. 2 ed. Rio de Janeiro: Civilização Brasileira, 2002.

LÖWY, Michael. O golpe de Estado de 2016 no Brasil. Carta Maior. 19 mai. 2016. Disponível em: <https://www.cartamaior.com.br/?/Editoria/Politica/O-golpe-de-Estadode-2016-no-Brasil/4/36139>. Acesso em 25 ago. 2018.

MARSHALL, T. H. Cidadania, classe social e status. Trad. De Meton Porto Gadelha. Rio de Janeiro: Zahar, 1967.

MÉSZÁROS, István. Igualdade substantiva e democracia substantiva. Margem Esquerda, São Paulo, Boitempo, n. 25, pp. 59-62, out. 2015.

NETTO, José Paulo. Democracia e Direitos Humanos na América Latina: aportes necessários ao debate. In: FREIRE, Silene (Org.) Direitos Humanos e Questão Social na América Latina. Rio de Janeiro: Gamma, 2009.

O'BRIEN. Edward L. Como educar a comunidade para a lei, a democracia e os Direitos Humanos. In: ANDREOPOULOS, George. CLAUDE, Richard P. Educação em Direitos Humanos para o século XXI. São Paulo: EDUSP, Núcleo de Estudos da Violência, 2007.

ONU. Organização das Nações Unidas. Declaração Universal dos Direitos Humanos, de 10 de dezembro 1948. Disponível em:

<https://www.unicef.org/brazil/pt/resources_10133.html>. Acesso em fev. 2016a.

OUTHWAITE, W. BOTTOMORE, Tom. Dicionário do pensamento social do século XX. Rio de Janeiro: Zahar, 1996.

PFEIFER, Mariana. O "social" no interior do projeto neodesenvolvimentista. Revista Serviço Social e Sociedade. São Paulo: Cortez, n. 120, p. 746-766, out./dez. 2014.

PINSKY, Jaime (Org.); PINSKY, Carla Bassanezi (Org.). História da Cidadania. São Paulo: Contexto, 2003.

POOLE, Hilary. et al (orgs). Direitos Humanos: referências essenciais. Traduzido por Fábio Larsson. Série Direitos Humanos: 3. São Paulo: EDUSP, Núcleo de Estudos da Violência, 2007.

RIZZINI, Irene. População infantil e juvenil: Direitos Humanos, Pobreza e Desigualdades. FREIRE, Silene (Org.) Direitos Humanos e Questão Social na América Latina. Rio de Janeiro: Gamma, 2009.

\begin{tabular}{l|l|l} 
Recebido em: 25/03/2019 & Aceito em: 30/04/2019 & Pg. 50 - 73
\end{tabular}




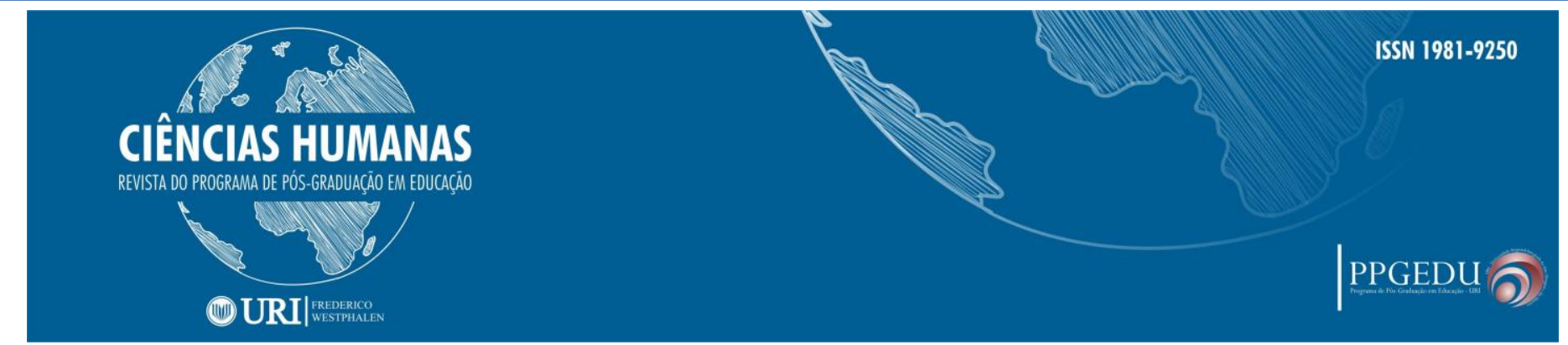

ROSSI, Marina. Brasil, a lanterna no ranking de participação de mulheres na política. El

País. São Paulo, 31 mar 2018. Disponível em:

<https://brasil.elpais.com/brasil/2018/03/27/politica/1522181037_867961.html>.

Acesso em 15 jan. 2019.

ROUSSEAU, Jean-Jacques. Do contrato social. Trad. Lourdes Santos Machado.

Coleção Os Pensadores. 2.ed. São Paulo: Abril Cultural, 1978.

SADER Emir. Brasil, de Getúlio a Lula. In: SADER, Emir. GARCIA, Marco Aurélio (Orgs.) Brasil, entre o passado e o futuro. São Paulo: Editora Fundação Perseu Abramo; Boitempo, 2010.

SANTOS, Boaventura de Souza. Democracia, Direitos Humanos e Globalização. Revista espaço acadêmico, n. 64, Universidade Estadual de Maringá, 2006.

SANTOS. Silvana Mara de Morais dos. Há necessidade dos direitos humanos para a formação de uma cultura política emancipatória? Temporalis. Ano 3, n.5. Brasília: ABEPSS, jan/jun, 2002.

TONET. Ivo. Democracia ou liberdade? 2.ed, Maceió: EDUFAL, 2004. 